\title{
Innovation networks and competitive coalitions in the pharmaceutical industry: The emergence and structures of a new industrial organization
}

\author{
Marc-Hubert Depret* and Abdelillah Hamdouch**
}

\begin{abstract}
Today, the pharmaceutical industry is subjected to wide-scale technological, institutional and economic changes that bring about a radical reconfiguration of the structural parameters and strategic variables of competition. While innovation processes are being increasingly structured around a new paradigm and markets are being both globalized and fragmented, firms are attempting to adapt, above all by refocusing their businesses and by redefining all the links in their value chain. However, the most significant changes in their strategy lie in the conception of their horizontal and vertical relations. The competitive game has a tendency to being extended to phases upstream market competition, to be reconfigured in the form of intra and inter-coalitions and networks strategic games, and to quickly evolve along with technological innovations, the opening of new market "frontiers" and successive concentration operations. The pharmaceutical industry thus constitutes a sort of life-size "laboratory" for an in-depth analysis of the effects of radical institutional and technological changes on the new shapes of competitive structuring within markets undergoing rapid globalization, and of the "spontaneous" emergence of a new form of industrial organization.
\end{abstract}

\section{Introduction}

In the image of many industrial or service sectors, the pharmaceutical industry is today subjected to wide-scale technological, institutional, and economic changes that bring about a radical reconfiguration of the structural parameters and strategic variables of competition: soaring "new biotechnology" (see Depret and Hamdouch, 2000b), in-depth redefinition of innovation processes, and continuous growth of R\&D costs; changes

\footnotetext{
* IFRESI-CLERSE, Université de Lille I, Faculté des Sciences Économiques et Sociales, 2 rue des Canonniers, 59800 Lille, France. E-mail: Marc-Hubert.Depret@ifresi.univ-lille1.fr

** CLERSE, Faculté des Sciences Économiques et Sociales, Université de Lille I, et MATISSE-CRIFES, Université de Paris I, Maison des Sciences Économiques, 106-112 boulevard de 1'Hôpital, 75647 Paris Cedex 13, France. E-mail: hamdouch@univ-paris1.fr

Keywords: New biotechnology applied to health, institutional and technological changes, competitive coalitions, globalization, pharmaceutical industry, innovation, interfirm networks.
} 
in legislation, market deregulation, and extension of the geographic area of competitive interaction for firms; rationalization of health expenditures; emergence of new therapeutic needs, and structural changes as regards drug demand, etc.

One of the most prevalent characteristics of this new context for competition lies in the concomitance of two apparently contradictory movements. On the one hand, competition is becoming sharper at the technological, industrial and commercial levels as markets open and become globalized; on the other hand, it seems to be becoming relativized or attenuated through the multiplication and diversification at a completely new level of cooperation and/or integration between firms that are current or potential rivals.

How can this "competitive paradox" be explained? If one is to refer to the usual approaches of industrial organization, there is no paradox at all: to escape head-on competition by prices, quantities or horizontal differentiation, rival firms in a market can decide to either "cooperate" by adopting collusive strategies, or purely and simply merge, within the more or less strict limits of national or international antitrust legislations.

This explanation, of course, holds a share of truth: the waves of mergers and acquisitions (M\&A) at the international level over the past twenty years in many sectors constitute a direct consequence, both structural (concentration via the elimination of part of the firms) and strategic (M\&A deals), of the globalization of competition.

This explanation, however, seems to be partial or limited, at least for three reasons. Firstly, the proliferation of cooperation agreements persists while the sectors being globalized have not ceased to concentrate. Concentration and cooperation therefore seem to be at least partly compatible.

Secondly, the traditional view of interfirm cooperation with an exclusively collusive goal hides all the cooperative strategies that are taking hold outside the markets (R\&D alliances, compatibility of norms and standards, etc.) and systematically assimilates cooperation with restriction in the competitive game. On the contrary, as this has already been demonstrated in many works, cooperation is extremely diversified in its forms and motivations and often contributes to preserving and stimulating a non-destructive competitive game (Teece, 1992; Jacquemin, 1994; Hamdouch, 1998).

Thirdly, and finally, the traditional approach to competition and cooperation only considers the relations between individual firms, assumed to be independent from each other outside the market, while interdependency within industrial groups and between companies are today a structural feature of a competitive game that is increasingly "collective".

In fact, this "competitive paradox", brought about by the different changes in progress, is without any real substance. It indeed appears through a new light when a more open and more dynamic approach is adopted as regards interfirm relations, as shown in the case of the drug industry, studied in this article. Thus, pharmaceutical companies confronted with these deep changes in institutions and technologies and with the quick reconfiguration of their competitive space, are now obliged to take on more "global" strategies, which are both highly costly and risky. Yet, paradoxically enough, globalization is demonstrated by a wider fragmentation of markets that requires capabilities and competences on the part of firms, suited to each type of market (traditional, new or potential markets, in terms of products and/or geographic areas). 
Within this context, no pharmaceutical company, no matter how powerful it may be, can hope to alone have an impact on the operation of markets and the determinants of their evolution. Thus, a firm's commitment in terms of relations of cooperation and/or integration today appears to be all the more constrained since all pharmaceutical companies are being subjected to this at the same time. This explains the gradual emergence of multilateral systems of interdependency. These interdependencies are reinforced by the globalization-fragmentation of markets that make it necessary for each firm to enter into specific partnerships on each targeted product or geographic market. However, the "stock" of potential partners in each market is all the more limited, on the one hand as all partners do not present the same strategic interest for the firm and, on the other hand, because this stock precisely has a tendency to be reduced as the markets become concentrated and alliances are made.

As a result, neither rivalry, nor cooperation or concentration can be apprehended any longer in terms of interaction purely or even essentially inter-individual. The analysis proposed in this article attempts precisely to show how, in the pharmaceutical industry, the competitive game is leaning towards expanding to phases upstream industrial competition, towards becoming reconfigured through struggles-cooperations among and between firm networks, and towards evolving quickly along with technological innovations, the opening of new markets, and successive concentration operations.

More broadly, the current changes in the pharmaceutical industry form a sort of lifesize "laboratory" for an in-depth analysis of the effects of radical institutional and technological changes on new shapes of competitive structuring within markets undergoing quick globalization, and of the "spontaneous" emergence of a new industrial organization. In this respect, it appears to offer a relatively original example of industrial selforganization ${ }^{1}$.

The concept of self-organization indeed helps explain the institutional, technological and industrial dynamics from circular interactions between the firms studied and their environment - which does not enable the framework of analysis based on Darwinian evolutionism (see Paulré, 1997). It thus becomes immediately possible to describe and understand ( $i$ ) the emergence of a "global" (Paulré, 1997) or "collective" order (Stengers, 1985), both selective and organized, based on "local" behaviour (Paulré, 1997), and (ii) changes (behavioural, strategic and/or organizational) in a system with respect to the nature of its interactions with its environment (Paulré, 1997). It is thus said that a system (company, organization, sector, etc.) possesses an ability for self-organization when it is able to, according to its experience and its environment (Yovits, 1962), "produce (in the presence of a "noise" or disequilibrium), on its own, and not necessarily in a voluntary or conscious way, a structure, organization, new behaviour and/or its own rules of operation" (Paulré, 1997, p. 134).

This is truly what seems to be happening today in the pharmaceutical industry, where we are witnessing at the same time the emergence of a new industry (that of new biotechnology; see Depret and Hamdouch, 2000b) and of a new model of technological

\footnotetext{
${ }^{1}$ For a presentation and discussion on recent research contributions on the theme of self-organization, see Paulré, 1997; Lesourne and Orléan, 1999.
} 
innovation based on the exploration of living organisms, and a radical reconfiguration of industrial structures and competitive strategies of the drug industry on the whole.

This article, as part of this theoretical perspective, attempts in this way to delimit the main explanatory factors of the current evolution dynamics of the pharmaceutical industry and to identify the prevalent traits of the new industrial organization that seems to be coming into being. The article has been divided into five sections. The first one briefly presents the general characteristics of the pharmaceutical industry and the structure of drug markets. Section 2 analyses the new bases of the competitive game brought about by the changes in progress in this industry and the strategies of adaptation used by pharmaceutical companies. Section 3 then brings out the dynamic, multidimensional nature and more and more interwoven nature of the modes of interaction amongst pharmaceutical companies, and between the latter and biotech companies. In fact, this increased phenomenon of interweaving illustrates not only the role, now extremely important, held by interfirm cooperation but also, and above all, the emergence and quick distribution of more and more hybrid and collective configurations of interaction in the form of firm coalitions and networks (Sect. 4). Then, the modes of forming, operation and the evolution of coalitions and networks indicate a broadened competitive dynamics in which the crucial determinants of market structures result from intra and inter-reticular strategic games (Sect. 5).

\section{The pharmaceutical industry: Specificity and market structures}

\subsection{The drug, a specific good}

\subsubsection{A supply under supervision and regulated all along the value chain}

A drug is not a good like others. Indeed, since it has an effect on the quality of life, on well-being and on disease, death or recovery, it is assimilated with a semi-public good or a good under supervision (Buisson and Giorgi, 1997). It is, as a result, subjected to many control agencies and to a complex network of national and international regulations (Richard and Senon, 1996; Walbrock-Rocha, 1997) that concern all levels of the value chain (Depret, 1999): R\&D, through the "Good Laboratory Practices" and the "Good Clinical Practices", that determine "International Common Denomination"; classification and industrial exploitation of the drug, via the approval (A.M.M. in France, FDA Approval in USA); production, import, export and distribution, through the "Good Manufacturing Practices" and specific conditions of access to advertising.

Innovation is thus closely structured by ethical considerations and the potential capability of production and sale is limited by regulation policies regarding health expenditure, while the combined effect of approval procedures, rules for prescription and reimbursement policies prevent any direct confrontation between supply and demand. Yet, however constraining they may be, statutory provisions produce, in parallel, a series of significant positive effects. In particular, sanitary safety encourages the quality of supply and the confidence of prescribers and patients, while rules of precaution are 
inclined to be recognized by all and to be harmonized from above (see de Wolf, 1993; Buisson and Giorgi, 1997).

\subsubsection{Drug demand, at the heart of health and reimbursement systems}

There is also a stake as regards demand for the entire sanitary channel as it relies closely on a chain of varied intermediaries. Upstream the end consumption of a drug, wholesalers play an ever more pronounced role. At the heart of the system, the patient-general practitioner pair gives direction to demand, while remaining tributary to pressure exerted by financing agencies for health expenditure. Public agencies are indeed subjected to a rationale to reduce the deficit of social expenditure and attempt to regulate demand by a tighter control of prescriptions and by modulating the reimbursement rates. As for the private systems, they play on the price to be paid for services (calls for tender and drawing up formularies).

\subsection{A relatively atomised, fragmented and segmented market}

\subsubsection{An oligopolistic, but highly dispersed structure}

Worldwide pharmaceutical industry is organized around a loose oligopoly (an important competitive fringe and high product differentiation), that is both stable and dynamic (Tarabusi, 1993), which means without really a new entry, but evolving internally along with firm strategies and the marketing of blockbusters $^{2}$ (see Tabs. 1 and 2).

Indeed, even if successive M\&A in the last two decades have demonstrated a gradual tightening of the industry and an increase in the market shares of the major pharmaceutical companies (see Tab. 3), the hard core of the oligopoly paradoxically represents only a relatively restricted share of the world market (see OCDE, 1985; Tarabusi and Vickery, 1996).

\subsubsection{Market fragmentation}

In spite of globalization, the particular aspect of domestic pharmaceutical markets sidesteps the competitive game and makes the industrial environment heterogeneous from one country to the next. There is even greater local market specificity: national statutory practices and health safety policies - that are either different or insufficiently harmonized -; cultural and human differences in clinical practice; heterogeneous modes of financing and consumption; etc.

\subsubsection{Market segmentation}

Two different approaches to market segmentation can be envisaged as regards drugs. The first one results from the combination of two criteria: the type of intellectual property

\footnotetext{
${ }^{2}$ A blockbuster is generally considered as a drug with yearly sales that exceed one billion dollars. In 1999, thirty were counted, nine of which exceeded two billion dollars (see Tab. 2).
} 
TABLE 1. Evolution of the top 20 pharmaceutical companies.

\begin{tabular}{|c|c|c|c|c|c|c|c|}
\hline $\begin{array}{c}99 \\
\text { Rank }\end{array}$ & $\begin{array}{c}89 \\
\text { Rank }\end{array}$ & $\begin{array}{c}82 \\
\text { Rank }\end{array}$ & Company & $\begin{array}{l}99 \text { Net } \\
\text { Sales }{ }^{(1)}\end{array}$ & $\begin{array}{c}99 \mathrm{R} \& \mathrm{D} \\
\text { Expenses }\end{array}$ & $\begin{array}{c}\text { R\&D } \\
\text { Effort }\end{array}$ & $\begin{array}{l}\text { Market } \\
\text { Share }\end{array}$ \\
\hline 1 & $2 / 8$ & $\begin{array}{c}18 / \mathrm{NC} \\
/ 11 / \mathrm{NC}\end{array}$ & GlaxoSmithKline $^{(2)}$ & 25.33 & 3.7 & $14.6 \%$ & $7.52 \%$ \\
\hline 2 & 15 & 6 & Pfizer & 22.86 & 3.8 & $16.6 \%$ & $6.79 \%$ \\
\hline 3 & 1 & 2 & Merck & 17.40 & 2.1 & $11.8 \%$ & $5.16 \%$ \\
\hline 4 & $\mathrm{NC}$ & $\mathrm{NC}$ & AstraZeneca ${ }^{(3)}$ & 14.83 & 2.1 & $14.2 \%$ & $4.40 \%$ \\
\hline 5 & 3 & $10 / 19$ & Bristol Myers Squibb & 14.30 & 1.7 & $11.9 \%$ & $4.24 \%$ \\
\hline 6 & $5 / 20$ & $4 / 20$ & Aventis ${ }^{(5)}$ & 13.50 & 2.3 & $17.0 \%$ & $4.01 \%$ \\
\hline 7 & $9 / 7$ & $5 / 9$ & Novartis ${ }^{(6)}$ & 11.37 & 1.6 & $14.1 \%$ & $3.37 \%$ \\
\hline 8 & 17 & 17 & Johnson\&Johnson & 10.70 & 1.6 & $15.0 \%$ & $3.17 \%$ \\
\hline 9 & $\begin{array}{c}\mathrm{NC} / 19 \\
/ \mathrm{NC}\end{array}$ & $\begin{array}{c}\mathrm{NC} / 17 \\
/ 16\end{array}$ & Pharmacia Corp ${ }^{(7)}$ & 10.66 & 2.1 & $19.8 \%$ & $3.16 \%$ \\
\hline \multirow[t]{2}{*}{10} & 12 & 7 & Eli Lilly & 10.00 & 1.7 & $17.0 \%$ & $2.97 \%$ \\
\hline & & & Total 10 & 150.9 & 22.7 & $15.0 \%$ & $44.8 \%$ \\
\hline 11 & 16 & 8 & Roche & 9.89 & 1.9 & $19.2 \%$ & $2.94 \%$ \\
\hline 12 & 10 & 3 & American Home Products & 9.50 & 1.5 & $15.8 \%$ & $2.82 \%$ \\
\hline 13 & 18 & $\mathrm{NC}$ & Schering-Plough & 7.70 & 1.1 & $14.3 \%$ & $2.29 \%$ \\
\hline 14 & 11 & 13 & Takeda & 5.83 & 0.7 & $12.4 \%$ & $1.73 \%$ \\
\hline 15 & 4 & 1 & Bayer & 5.35 & 1.3 & $24.3 \%$ & $1.59 \%$ \\
\hline 16 & $\mathrm{NC}$ & $\mathrm{NC}$ & BASF & 5.30 & 1.2 & $22.6 \%$ & $1.57 \%$ \\
\hline 17 & $\mathrm{NC}$ & $\mathrm{NC}$ & Sanofi-Synthelabo ${ }^{(8)}$ & 5.15 & 0.9 & $17.0 \%$ & $1.53 \%$ \\
\hline 18 & $\mathrm{NC}$ & $\mathrm{NC}$ & Sankyo & 5.08 & 0.6 & $11.6 \%$ & $1.51 \%$ \\
\hline 19 & $\mathrm{NC}$ & $\mathrm{NC}$ & Boehringer Ingelheim & 4.93 & n.d & n.d & $1.46 \%$ \\
\hline \multirow[t]{2}{*}{20} & $\mathrm{NC}$ & $\mathrm{NC}$ & Shionogi & 3.50 & n.d & n.d & $1.04 \%$ \\
\hline & & & Total 20 & 213,17 & $33,1^{(\mathrm{e})}$ & $15,56 \%$ & $63.28 \%$ \\
\hline
\end{tabular}

(1) Sales, R\&D expenses and R\&D effort in billions of dollars; R\&D effort as \% of sales; 99 world market share; ${ }^{(2)}$ GlaxoSmithKline $=$ Glaxo + Wellcome + Smithkline Beckman + Beecham; ${ }^{(3)}$ AstraZeneca $=$ Astra + Zeneca; ${ }^{(4)}$ Bristol Myers Squibb = Bristol Myers + Squibb; ${ }^{(5)}$ Aventis $=$ Rhône-Poulenc + Hoechst $;{ }^{(6)}$ Novartis $=$ Ciba-Geigy + Sandoz $;{ }^{(7)}$ Pharmacia Corp. $=$ Pharmacia \& Upjohn + Monsanto $;{ }^{\left({ }^{8}\right)}$ Sanofi-Synthélabo = Sanofi + Synthélabo; NC: Not Classified in the first twenty pharmaceutical companies before merger or acquisition; ${ }^{(e)}$ Estimate by defect.

Sources: Calculations by the Authors from Hamdouch and Depret (2000) and Pharmaceutical Executive (2000).

rights applicable (drug protected by a patent versus a patent that has fallen into the public domain), and the terms of sale (subject to prescription or not). It enables three types of drugs, for which the rules of operation on markets are highly heterogeneous (see Depret, 
TABLE 2. The top 25 best-selling global products.

\begin{tabular}{|c|c|c|c|}
\hline Rank & Product(s) & Company & 99 Net Sales ${ }^{(1)}$ \\
\hline 1 & Prilosec & AstraZeneca & 5.9 \\
\hline 2 & Zocor & Merck & 4.49 \\
\hline 3 & Lipitor & Warner-Lambert & 3.7 \\
\hline 4 & Norvasc & Pfizer & 3.03 \\
\hline 5 & Claritin & Schering-Plough & 2.7 \\
\hline 6 & Prozac & Eli Lilly & 2.6 \\
\hline 7 & Vasotec & Merck & 2.3 \\
\hline 8 & Paxil & SmithKline Beecham & 2.1 \\
\hline 9 & Zoloft & Pfizer & 2.03 \\
\hline \multirow[t]{2}{*}{10} & Augmentin & SmithKline Beecham & 1.8 \\
\hline & & Top 10 & 30.65 \\
\hline 11 & Zyprexa & Eli Lilly & 1.8 \\
\hline 12 & Premarin & American Home Products & 1.8 \\
\hline 13 & Epogen & Amgen & 1.76 \\
\hline 14 & Pravachol & Bristol Myers Squibb & 1.7 \\
\hline 15 & Insulin & Novo Nordisk & 1.7 \\
\hline 16 & Cipro & Bayer & 1.63 \\
\hline 17 & Celebrex & Monsanto (Searle) & 1.5 \\
\hline 18 & Taxol & Bristol Myers Squibb & 1.4 \\
\hline 19 & $\begin{array}{l}\text { Cozaar } \\
\text { /Hyzaar }\end{array}$ & Merck & 1.38 \\
\hline \multirow[t]{2}{*}{20} & Zithromax & Pfizer & 1.3 \\
\hline & & Top 20 & 46.62 \\
\hline 21 & Glucophage & Bristol Myers Squibb & 1.3 \\
\hline 22 & Zestril & AstraZeneca & 1.2 \\
\hline 23 & Sandimmun & Novartis & 1.2 \\
\hline 24 & $\begin{array}{l}\text { Flixotide } \\
\text { /Flovent }\end{array}$ & GlaxoWellcome & 1.07 \\
\hline \multirow[t]{2}{*}{25} & Humulin & Eli Lilly & 1.06 \\
\hline & & Top 25 & 52.45 \\
\hline
\end{tabular}

(1) Sales in billions of dollars.

Source: Pharmaceutical Executive (2000).

1999). On the patented ethical products market, competition is essentially upstream as it results basically from an "innovation race" opposing R\&D teams on several "therapeutic fronts". Once the product has been patented, competition on this market is therefore gen- 
TABLE 3. Evolution of the Concentration of World Pharmaceutical Industry (Lerner Indexes*)

\begin{tabular}{|ccccc|}
\hline $\mathrm{C}_{\mathrm{i}}:$ & 1982 & 1989 & 1996 & 1999 \\
\hline $\mathrm{C}_{4}$ & $13,0 \%$ & $11.4 \%$ & $16.1 \%$ & $23.9 \%$ \\
\hline $\mathrm{C}_{8}$ & $22.9 \%$ & $20.9 \%$ & $27.9 \%$ & $38.7 \%$ \\
\hline $\mathrm{C}_{10}$ & $27,0 \%$ & $25,0 \%$ & $33,0 \%$ & $44.8 \%$ \\
\hline $\mathrm{C}_{16}$ & $38.3 \%$ & $34.4 \%$ & $44.8 \%$ & $57.7 \%$ \\
\hline $\mathrm{C}_{20}$ & $44,0 \%$ & $41.2 \%$ & $51.1 \%$ & $63.3 \%$ \\
\hline
\end{tabular}

* Lerner indexes $\mathrm{C}_{\mathrm{i}}=$ market share cumulated of the first $\mathrm{i}$ companies, as \% of global market.

Sources: Calculations by the Authors from Hamdouch and Depret (2000) and Pharmaceutical Executive (2000).

erally not head-on; it becomes (a little more so) when the drug falls into the public domain. Indeed, manufacturers of generic drugs, who are not obliged to bear R\&D costs and who benefit from a commercial effort of the innovative firm, only place their effort downstream the value chain ${ }^{3}$. They continue to be subjected, however, to rules regarding bans on advertising. Yet the latter is not imposed on manufacturers of "OTC" (over the counter) products that can launch advertising campaigns in all media. In the latter case, competition is subjected to arbitration, no longer on the part of prescribers, but on the part of consumers.

The second approach of the market segmentation, by therapeutic category, enables the relevant markets to be detected more precisely on which technological and industrial competition between pharmaceutical companies takes hold. So, while in 1995 nearly twenty thousand drugs were counted on the market (Colcombet and Aflalo, 1995), a classification into fifteen consistent therapeutic categories (see Tab. 4) illustrates two particularly important observations (Depret, 1999). On the one hand, the market appears to be highly segmented and concentrated at the same time, since the first three and five therapeutic categories cover respectively nearly $51 \%$ and a little over $70 \%$ of the market. On the other hand, regardless of their size, pharmaceutical companies generally opt for a relative therapeutic specialization due to the high cost of pharmaceutical innovation (Depret, 1999). However, while large pharmaceutical companies are practically all present in the most important therapeutic categories, the smallest firms, on the contrary, practice very tight specialization by being positioned only on one or two promising or highly advanced domains (Iung and Rupprecht, 1997). In fact, at the therapeutic level,

\footnotetext{
${ }^{3}$ It is to be noted that to counter the inevitable expansion of the generic drug market (Alvarez, 1994; Martin and Rupprecht, 1998), innovative pharmaceutical companies have also entered the market by external growth, by the creation of a dedicated division or by strategic alliances (Colcombet and Aflalo, 1995; Tarabusi and Vickery, 1996).
} 
TABLE 4. The world pharmaceutical market by therapeutic category (1998).

\begin{tabular}{|clcc|}
\hline Rank & \multicolumn{1}{c}{ Therapeutic Category } & $\begin{array}{c}\text { Market } \\
\text { share }\end{array}$ & Cumulative \\
\hline 1 & Cardiovascular & $19.9 \%$ & $19.9 \%$ \\
\hline 2 & Alimentary \& Metabolism & $15.8 \%$ & $35.7 \%$ \\
\hline 3 & Central Nervous System & $15.0 \%$ & $50.7 \%$ \\
\hline 4 & Anti-infectives & $10.6 \%$ & $61.3 \%$ \\
\hline 5 & Respiratory & $9.4 \%$ & $70.7 \%$ \\
\hline 6 & Genito Urinary & $5.3 \%$ & $76.0 \%$ \\
\hline 7 & Musculo-skeletal & $5.0 \%$ & $81.0 \%$ \\
\hline 8 & Dermatologicals & $4.0 \%$ & $85.0 \%$ \\
\hline 9 & Cytostatics & $3.6 \%$ & $88.6 \%$ \\
\hline 10 & Miscellaneous & $3.4 \%$ & $92,0 \%$ \\
\hline 11 & Blood agents & $2.9 \%$ & $94.9 \%$ \\
\hline 12 & Sensory Organs & $2.2 \%$ & $97.1 \%$ \\
\hline 13 & Hormones & $1.7 \%$ & $98.8 \%$ \\
\hline 14 & Hospital Solutions & $1.0 \%$ & $99.8 \%$ \\
\hline 15 & Parasitology & $0.2 \%$ & $100 \%$ \\
\hline & & & \\
\hline
\end{tabular}

Source: Depret (1999).

the market is characterized by a higher concentration than at the global level and by a relatively important share of the leading firm ${ }^{4}$.

Thus, the notion of a relevant market constitutes a notion of variable geometry: it depends closely on what is being considered (geographic area, nature of the drug, therapeutic category, etc.). However, while this highly specific structuring of drug markets demonstrates a relative fractioning of the competitive game, the changes in progress in this industry bring about an in-depth reconfiguration of markets and of their geographic and therapeutic boundaries.

\section{New foundations of the competitive game and strategic adaptation of pharmaceutical companies}

The pharmaceutical industry is currently affected by five types of structural changes. These changes, which oblige firms to make significant strategic and organizational adaptations, are creating the new foundations (or "rules") of the competitive game within this sector.

\footnotetext{
${ }^{4}$ For example, the insulin market, controlled for over twenty years by Novo Nordisk and Eli Lilly (which hold between two-thirds and three-quarters of the world market) is practically a duopoly (Hamdouch and Depret, 2000). Novo Nordisk and Eli Lilly indeed allow followers (such as Hoechst in Europe) only several shares of domestic markets (Durand and Gonard, 1986).
} 


\subsection{Radical changes in progress in the pharmaceutical industry}

\subsubsection{Rationalizing health expenditures and limiting the growth of firms}

The combined actions of a slowdown in growth in the 1980s, of the Engel's Law - with health expenditures increasing two to three times faster than income; see Colcombet and Aflalo (1995) -, soaring unemployment and the "grandpa boom" are all at the origin of the crisis of the financing systems and of the rationalization policies of health expenditures begun in many countries. These policies have led to a slowdown in the growth of pharmaceutical companies, while the pressure of the public authorities and new players (Health Management Organizations and Pharmaceutical Benefit Managers 5 , patient associations, generic drug manufacturers, etc.) limited the increase in drug prices, weighing down on the margins, on the ability for self-financing, and therefore, in fine, on the pharmaceutical industry's ability for innovation.

\subsubsection{Growing needs for innovation and increase in the critical size of $R \& D$}

The institutional and financial pressure exerted on the industry is all the more strong as the pharmaceutical companies must bear very high R\&D investments $(14.2 \%$ of turnover in France; S.N.I.P., 1999) that are growing rapidly (increase in Europe of over 72\% between 1986 and 1995; see Scrip Magazine, 15 January 1999), on the one hand, because the innovative processes are forever longer and more costly ${ }^{6}$, and, on the other hand, due to the medical needs that must be satisfied ${ }^{7}$, from the maturity of "pipelines" 8 (see Tab. 5) and the ageing of product portfolios ${ }^{9}$, all in a context of market globalization and intensified competition.

Pharmaceutical companies are thus obliged to "run" after their optimal size, i.e. the size ${ }^{10}$ enabling them to reconcile on the one hand a relative specialization of the therapeutic segments covered and a concentration of research products in some broad fields

\footnotetext{
${ }^{5}$ Health Management Organizations are American private organizations in charge of managing the health services of companies. As for Pharmaceutical Benefit Management companies, they are management companies for medical prescriptions ensuring the handling of prescriptions and drug distribution (see Hamdouch and Perrochon, 1999b).

${ }^{6}$ The average period between initial research and the sale of a product varies between eleven and fourteen years, the average cost for a new molecule being between two and three billion French Francs, with an increasing share devoted to development (51.5\% of R\&D expenses in 1997, as opposed to $35.5 \%$ in 1970), leaving $33 \%$ to applied research and $15.5 \%$ to fundamental research (S.N.I.P., 1997).

${ }^{7}$ Also included here are cardiovascular disorders, diabetes, cancer, chronic respiratory disorders, degenerative diseases, psychiatric and neurological disorders, Aids, etc.

${ }^{8}$ A pipeline can be defined as the portfolio of molecules developed by each laboratory (Spikler, 1993; Dumoulin, 1994). It is said that a pipeline is mature when it is made up of a great number of molecules in a phase of clinical development.

${ }^{9}$ Indeed, half of the one hundred most widely sold drugs in the world must fall into the public domain by the year 2005 (see Beynon, 2000).

${ }^{10}$ As a reminder, size seems to present four advantages in terms of R\&D (Schumpeter, 1961; Fisher and Temin, 1973; Panzar and Willig, 1981; Cohen and Levinthal, 1989; Mairesse and Mohen, 1990; Foray and Le Bas, 1991; Henderson and Cockburn, 1997): (i) economies of scale and scope; (ii) diversification of research efforts; (iii) favoured access to financial markets; (iv) spillovers.
} 
TABLE 5. Top 20 R\&D pipelines (Number of active products - May 1999).

\begin{tabular}{|c|c|c|c|c|}
\hline Rank & Company & $\begin{array}{c}\text { No. of R\&D } \\
\text { Drugs }\end{array}$ & $\begin{array}{l}\text { No. And \% } \\
\text { of Own Drugs }\end{array}$ & $\begin{array}{l}\text { No. And } \% \text { of Drugs } \\
\text { in Licensing }\end{array}$ \\
\hline 1 & GlaxoSmithKline & 206 & $126(61.2 \%)$ & $80(38.8 \%)$ \\
\hline 2 & AstraZeneca & 166 & n.d & n.d \\
\hline 3 & Aventis & 148 & $79(53.4 \%)$ & $69(46.6 \%)$ \\
\hline 4 & Pfizer & 146 & $81(54.4 \%)$ & $65(45.4 \%)$ \\
\hline 5 & Roche & 122 & $67(54.9 \%)$ & $55(45.1 \%)$ \\
\hline 6 & American Home Products & 93 & $43(46.2 \%)$ & $50(53.8 \%)$ \\
\hline 7 & Merck & 89 & $64(71.9 \%)$ & $25(28.1 \%)$ \\
\hline 8 & Novartis & 89 & $53(59.6 \%)$ & $36(40.4 \%)$ \\
\hline 9 & Pharmacia\&Upjohn & 80 & $43(53.7 \%)$ & $37(46.3 \%)$ \\
\hline 10 & Eli Lilly & 74 & $39(52.7 \%)$ & $35(47.3 \%)$ \\
\hline 11 & $\mathrm{NIH}$ & 73 & $69(94.5 \%)$ & $4(5.5 \%)$ \\
\hline 12 & Johnson\&Johnson & 73 & $30(41.9 \%)$ & $43(58.9 \%)$ \\
\hline 13 & Abbott & 72 & $36(50.0 \%)$ & $36(50.0 \%)$ \\
\hline 14 & Boehringer Ingelheim & 68 & $48(70.6 \%)$ & $20(29.4 \%)$ \\
\hline 15 & Bristol Myers Squibb & 68 & $32(47.1 \%)$ & $36(52.9 \%)$ \\
\hline 16 & Schering AG & 67 & $44(65.7 \%)$ & $23(34.3 \%)$ \\
\hline 17 & Bayer & 59 & $43(72.9 \%)$ & $16(27.1 \%)$ \\
\hline 18 & Yamanouchi & 59 & $37(62.7 \%)$ & $22(37.3 \%)$ \\
\hline 19 & Schering Plough & 58 & $21(36.2 \%)$ & $37(63.8 \%)$ \\
\hline 20 & Novo Nordisk & 53 & $36(67.1 \%)$ & $17(32.1 \%)$ \\
\hline & Total 20 & 1863 & & \\
\hline
\end{tabular}

Source: Calculations by the authors from Pharmaprojects (2000).

(maximum exploitation of economies of scale and scope), and, on the other hand, the need to hold more dispersed investments with a highly uncertain return (Cockburn and Henderson, 1998), but necessary in order to maintain a sufficient "absorptive capacity" (Cantner and Pyka, 1998; Cohen and Levinthal, 1989, 1990).

\subsubsection{Market globalization and the opening of "new frontiers"}

While the critical size of R\&D is increasing, this is also due to the fact that the relevant markets are henceforth continental or transcontinental, and will be tomorrow, in a therapeutic category, ever increasingly global. The world market is estimated at 334 billion dollars (1999), and expected to reach 435 billion dollars in 2003 and 690 billion dollars in 2010 (IMS, 1999). It is characterized by strong growth (6 to $8 \%$ per year) and the preponderance of developed countries ( $85 \%$ of the market). However, new markets are emerging (Latin America, Asia, Central and Eastern Europe). The Asian market is 
TABLE 6. The world pharmaceutical market by regional market.

\begin{tabular}{|lccc|}
\hline \multicolumn{1}{|c}{ Regional Market } & 1980 & 1997 & $2004 *$ \\
\hline NORTH AMERICA & $20.4 \%$ & $36.1 \%$ & $41.8 \%$ \\
\hline EUROPE & $35.9 \%$ & $30.4 \%$ & $27.4 \%$ \\
of which Eastern Europe \& CIS & $\mathrm{n} . \mathrm{s}$ & $1.4 \%$ & $2.6 \%$ \\
\hline JAPAN & $18.2 \%$ & $19.1 \%$ & $11.3 \%$ \\
\hline REST of the WORLD & $25.5 \%$ & $14.4 \%$ & $19.5 \%$ \\
of which Latin America \& Caribbean & $\mathrm{n} / \mathrm{a}$ & $7.7 \%$ & $7.5 \%$ \\
of which China & $\mathrm{n} / \mathrm{a}$ & $2.0 \%$ & $5.0 \%$ \\
of which India & $\mathrm{n} / \mathrm{a}$ & $1.4 \%$ & $1.8 \%$ \\
of which Pacific & $\mathrm{n} / \mathrm{a}$ & $1.3 \%$ & $1.3 \%$ \\
of which Middle East & $\mathrm{n} / \mathrm{a}$ & $2.0 \%$ & $3.9 \%$ \\
\hline
\end{tabular}

* Estimate; ns: not significant; n/a: not available.

Sources: S.N.I.P. (1999); Eurasanté (1999a); Colcombet and Aflalo (1995).

expected to undergo the highest growth rate of the next century (11\% per year), particularly the Chinese market (18-19\% per year by the year 2004; see IMS, 1999).

These paths represent real opportunities for firms seeking renewed sources of growth. Indeed, as cost and the importance of experience in R\&D limit the opportunities for therapeutic diversification outside the specialization base, essentially (internal and/or external) growth on new markets may finance the future R\&D of pharmaceutical companies. The opening of borders, at the same time, demonstrates the arrival of outsiders and increased market fragmentation. Therefore, pharmaceutical companies must manage the specificity of the new markets, while remaining vigilant with respect to new competitors in markets where they are already present.

\subsubsection{Towards a new paradigm of pharmaceutical innovation}

This is where the changes in progress are undoubtedly the strongest (see Depret and Hamdouch, 2000b). The irruption of new biotechnology (or third generation biotechnology) indeed draws the contours of a new technological paradigm that is quickly shaping the innovation processes and the competitive dynamics of the drug industry (based on the notion of technological paradigm, see Dosi, 1982).

Today, if new biotechnology techniques applied to health are presented as an alternative to the chemistry paradigm (Chesnais, 1981) and to methods that have however been rationalized (Dumoulin, 1994), it is because they enable the development of more effective drugs that are less expensive and launch on the market more quickly and, more particularly, because they enable intervention no longer on the effects of a pathology but on its causes (Eurasanté, 1999a; Depret and Hamdouch, 2000b). Thus, the patient can be treated in two different but complementary ways: $(i)$ by acting "directly" on the gene or protein to be "repaired", thanks to what is known as DNA-based therapy; (ii) by 
improving current treatments or by creating new drug solutions thanks to the tools offered by "technological platforms" 11 .

New biotechnology applied to health in this way draw the new "technological frontiers" that superpose the new "geographical frontiers" brought about by globalization. They are indeed at the origin of the introduction and generalization of new innovation routines that impose the creation and gathering of new competences. In fact, pharmaceutical innovation can today be considered as the result of ever more knowledge in different disciplines and sectors induced by the convergence of the technological trajectories of the pharmaceutical industry, biotechnology, information technology (bioinformatics) and electronics (biochips).

\subsubsection{Towards broader coordination amongst the players}

The multidisciplinary nature of the knowledge and competences required obliges pharmaceutical companies to make the contributions and pressure exerted from new industrial players part of their strategy, particularly biotech companies. Their responsiveness, flexibility and critical "savoir-faire" therefore help pharmaceutical companies to make ever-closer ties.

At the same time, other institutional players are appearing, also changing the rules of the game. What can be seen is the growing role of retirement funds and big business investors who limit room for decisions on the part of company leaders, sometimes obliging them to make radical strategic choices ${ }^{12}$.

"Worked" in an endogenous and exogenous manner by wide-scale technological, economic and institutional changes, the pharmaceutical industry is thus marked by a radical redefinition of its structural determinants and its competitive dynamics. How do pharmaceutical companies face the new "rules of the game"? Are they content with adapting to them by limiting the less favourable consequences, or are they, on the contrary, seeking to channel them or even to redefine them to their best advantage?

\subsection{New rules of the game or game on the rules?}

Contrary to what may have been initially thought, the combination and the quasi-simultaneity of the structural changes described above were not at the origin of a total and

\footnotetext{
${ }^{11}$ In biotechnology, five technological platforms can be considered: (i) genomics, for a better understanding of diseases so as to identify the pharmacological targets on which new drugs will be able to act; (ii) Bioinfomatics which enables computer-aided modeling and the "in silico" identification of drug candidates; (iii) biochips, to pave the way for innovation in the field of diagnostics and in the discovery of new drugs, but above all for an accelerated understanding of their modes of action; (iv) combinatorial chemistry and high throughput screening, which give researchers a method for drug creation at a speed ten thousand times higher and at a cost ten times less than the traditional blind screening, by creating chemical diversity that was not fathomable only a few years ago; (v) finally, "drug delivery", for better screening of drug action, with greater therapeutic efficiency and/or reduced side effects (see Depret and Hamdouch, 2000b).

${ }^{12}$ This is how Hoechst, for example, had to comply with the terms of its main shareholder (Kuwaiti KPC), that called for (and obtained) both an acceleration of the merger process with Rhône-Poulenc, a double split (Hoechst-Celanese and Rhône Poulenc-Rhodia), and the setting up of the new Group (Aventis) in Strasbourg. See L'Expansion 607, Oct. 1999, pp. 92-94.
} 
erratic questioning of the structure of markets within the pharmaceutical industry. This situation, seemingly paradoxical, can be explained in fact, not by a limited impact of these changes or by a weak influence of the new industrial or institutional players, but rather by the remarkable effort in adapting pharmaceutical companies to the new technological, industrial and competitive rules of the game in this sector.

Indeed, as already demonstrated (see particularly Delapierre et al., 1998), it appears that while an insider manages to impose its rules, it temporarily keeps control and can create conditions for making the competitive regime it masters last, particularly with respect to outsiders ${ }^{13}$. Firms wishing to enter into business must then, either meet all these rules (anterior position of biotech companies), or modify or create new ones, by attempting to, for example, have an innovation adopted that it has itself initiated (as it is today the case for biotech companies).

In the case of the pharmaceutical industry, this game on the rules between the insiders (pharmaceutical companies), and between the latter and the different outsiders (biotech companies and new institutional players) includes the commitment of pharmaceutical companies in strategies of adaptation as well as the radical reconfiguration of the industrial and competitive industrial organization of the drug industry on the whole.

\subsection{Imperative organizational and strategic reorientations}

\subsubsection{Radical strategic refocusing on core businesses}

After having attempted to develop through diversification and vertical integration which explains the excessive dispersion of investment and research efforts -, pharmaceutical companies have been developing over several years split strategies between chemical and pharmaceutical businesses, and more recently between pharmaceutical and agrochemical businesses, as well as strategies for the transfer of business activities deemed as non-strategic. These strategies (see Perrochon, 2000) mark the end of the vertically integrated pharmaceutical company, as it seeks, develops, produces and sells only its own drugs.

Today, this new direction appears all the more imperative as the arrival or increase in the power of the new industrial and institutional players exert additional pressure on pharmaceutical companies at three main levels: (i) exacerbated competition and a contraction of margins; (ii) increased dependency of pharmaceutical companies with respect to public or private funding bodies through different systems of contractual regulation; (iii) and finally, consumption more and more guided by individual care costs and by public prevention policies.

\footnotetext{
${ }^{13}$ In the pharmaceutical industry, barriers to entry are three-fold: statutory (see Sect. 1), technical and economic (necessary competence for the exploitation of pharmaceutical innovation), and commercial - when we know that only blockbusters are sufficiently profitable to be able to bear all the costs pertaining to the development and setting up of production capacities and the required sales resources. So, several studies demonstrate that investments only begin to be covered after the patent has expired (see for example: Grabowski and Vernon, 1990, 1994; Guillot and Simon, 1991).
} 


\subsubsection{Towards a rationalization of organizational structures}

While the global strategy must be reviewed in depth, the same applies for each link of the value chain that pharmaceutical companies are seeking to rationalize to the full. Upstream, we are witnessing a double movement of therapeutic refocusing and decentralization - or even the outsourcing - of R\&D activities. At the production level, pharmaceutical companies, have set up reduction programmes and site specializations, and have accentuated resorting to custom-made production of specialties. Finally, downstream, we are witnessing a double organizational and strategic evolution: on the one hand, marketing has been reinforced as the first budget item (24\% of turnover since the beginning of the 90s; see Tarabusi and Vickery, 1996), with the emergence of new promotional tools (co-marketing, co-promotion, etc.); on the other hand, the distribution chain has been rationalized as a result of the development of generic substitution, selfmedication and concentration of the European market (Eurasanté, 1999b; Depret, 1999).

Beyond these strategic and organizational changes, the defence and conquest of market shares means redefining the modes of interfirm interaction and adopting complex and changing strategic combinations for these modes.

\section{Nature and evolution of interfirm relations in the pharmaceutical industry}

The evolution in the relations between pharmaceutical companies, and between the latter and biotech companies, perfectly illustrates the new strategies of interfirm interaction in the sectors undergoing wide-scale technological, institutional and economic changes. Indeed, while in the drug industry these relations have always been marked by diversity, evolution and the combination of modes of interaction, today, they are becoming more complex as they are part of increasingly hybrid and dynamic configurations.

\subsection{Diversity of the modes of interfirm interaction}

To define the nature of interfirm relations in the pharmaceutical industry, according to Hamdouch and Perrochon (1999b), we consider that a continuum of dynamic configurations of interaction in which head-on rivalry, cooperation and integration/concentration constitute only "generic attractors" of interfirm interaction trajectories.

\subsection{1. "Relativized" competition on markets}

Within the pharmaceutical industry, direct competition exists only in a loose form, for two main reasons. Firstly, the existence of "industrial organization networks" 14

\footnotetext{
14 This notion must not be confused with the informal networks of top executives described by Froelicher (1996).
} 
(national, transnational or international ${ }^{15}$ ) ensures the close institutional coordination between pharmaceutical companies that share, at least partially, "common interests" ${ }^{16}$.

Secondly, the relative specialization of pharmaceutical companies in some therapeutic areas, and the highly uncertain nature of innovation in this field make it improbable for two pharmaceutical companies conducting research on the same pathology, with the same approach to the solution, and with, in the end, two galenic forms with identical side effects, to launch the product on the market at the same time. Rivalry on pharmaceutical markets thus appears to be essentially guided by the nature of the pathology and the treatment, by the patient's case history, by the prescriber's and patient's habits, and more and more by generic substitution.

\subsubsection{Integration strategies vs. outsourcing and/or cooperation strategies}

In the pharmaceutical industry, taking the example of most industrial or service sectors, external growth strategies have been developing considerably over the past years, in successive waves ${ }^{17}$ (see Tab. 7). In this sector, the motivations for such movements are numerous (see Depret and Hamdouch, 2000a): an increase in the R\&D critical size, research into technological, productive or commercial synergy, the stabilization or increase in market shares in a globalized environment; and more tacitly: the eventual expiry of a patent on a blockbuster while the pharmaceutical company has no alternative new product, the need to create value for the shareholders, or yet the attenuation of the strategic consequences resulting from a poor technological or commercial former choice...

Theoretically, the current M\&A wave in the pharmaceutical industry can be explained in two ways. As for the context, it corresponds to a "natural" strategic reversal on the part of firms. Thus, in an industry undergoing change, cooperative strategy is no longer suited to the quick technological, productive and commercial changes required (heavy interfirm coordination, project blockage, difficulty in establishing alternative partnerships which are strategically more advantageous, etc. (see Hamdouch and Perrochon, 1999b).

More structurally, based on the new-institutional approach, cooperation is considered as the sole solution to a problem of uncertainty (Quéré and Ravix, 1996). It then appears

\footnotetext{
${ }^{15}$ In France, pharmaceutical companies are organized within the National Pharmaceutical Industry Union (S.N.I.P.), member of the European Federation of Pharmaceutical Industry Associations (E.F.P.I.A.) and the International Federation of Pharmaceutical Manufactors Associations (I.F.P.M.A.).

${ }^{16}$ These networks finance regular studies on the evolution of markets, legislation and technologies, organize conferences and colloquia on a wide number of topics, and adopt common positions with participating firms so as to be heard by representative authorities and consumer associations.

${ }^{17}$ While from 1988 to 1992 , over two hundred cross-border M\&A operations were carried out in the pharmaceutical industry for a total amount of 13.1 billion dollars (Tarabusi and Vickery, 1996), they are today at a much higher scale, above all due to the mechanical increase in the size of pharmaceutical companies brought about by successive concentration operations. It is also important to stress that current operations bear essentially on mergers between firms of a comparable (significant) size: Ciba-Geigy and Sandoz (Novartis), Astra and Zeneca, Hoechst and Rhône Poulenc-Rorer (Aventis), Sanofi and Synthélabo, and on current operations (see Tab. 7).
} 
TABLE 7. Major mergers and acquisitions deals in pharmaceutical industry since 1988.

\begin{tabular}{|c|c|c|c|c|}
\hline \multicolumn{2}{|r|}{ Company 1} & Company 2 & New identity & Value $^{(5)}$ \\
\hline \multirow{3}{*}{1988} & Eastman Kodak (USA) & Sterling\&Winthrop (USA) & Eastman Kodak & 5.3 \\
\hline & Smithkline Beeckman (USA) & Bio Science Labs (USA) & Smithkline Beeckman & 7.8 \\
\hline & Boehringer Ingelheim (Ger) & Bio Mega (USA) & Boehringer Ingelheim & $\mathrm{n} / \mathrm{a}$ \\
\hline \multirow{7}{*}{1989} & Novo (Danmark) & Nordisk (Danmark) & Novo Nordisk & $\mathrm{n} / \mathrm{a}$ \\
\hline & Merrell Dow (USA) & Marion (USA) & Marion Merrell Dow & 7.7 \\
\hline & Smithkline Beeckman (USA) & Beecham (GB) & Smithkline Beecham & merger \\
\hline & Bristol Myers (USA) & Squibb (USA) & Bristol Myers Squibb & 12.7 \\
\hline & Fujisama (Japan) & Lyphomed (USA) & Fujisama & $\mathrm{n} / \mathrm{a}$ \\
\hline & Institut Merieux (France) & Connaught (Canada) & Merieux & $\mathrm{n} / \mathrm{a}$ \\
\hline & Pricordio AB (Sweden) & Pharmacia AB (Sweden) & Pharmacia & 2.44 \\
\hline \multirow{2}{*}{1990} & Rhône-Poulenc (France) & Rorer (USA) & Rhône-Poulenc Rorer & 3.476 \\
\hline & Merck\&Co (Switzerland) & du Pont de Nemours (USA) & Merck\&Co & 2.5 \\
\hline 1991 & Sanofi (France) & Sterling Drug Europe (USA) & Sanofi & $\mathrm{n} / \mathrm{a}$ \\
\hline \multirow{3}{*}{1992} & American Cyanamid (USA) & Immunex (USA) & American Cyanamid & 0.736 \\
\hline & Pharmacia (Sweden) & Montedison (Italy) ${ }^{(1)}$ & Pharmacia & $\mathrm{n} / \mathrm{a}$ \\
\hline & Warner Lambert OTC (USA) & Wellcome OTC (GB) & Warner Lambert OTC & 4.397 \\
\hline \multirow{2}{*}{1993} & Merck (USA) & Medco (USA) & Merck & 6.6 \\
\hline & Hoechst (Germany) & Copley (USA) & Hoechst & 0.546 \\
\hline \multirow{9}{*}{1994} & Roche (Switzerland) & Syntex (USA) & Roche & 5.307 \\
\hline & $\begin{array}{l}\text { Smithkline Beecham (USA/ } \\
\text { GB) }\end{array}$ & Diversified Phar.Serv. (USA) & Smithkline Beecham & 2.3 \\
\hline & AHP (USA) & American Cyanamid (USA) & $\mathrm{AHP}^{(4)}$ & 9.561 \\
\hline & Sanofi (France) & Sterling Winthrop (USA) ${ }^{(2)}$ & Sanofi & 1.68 \\
\hline & $\begin{array}{l}\text { Smithkline Beecham (USA/ } \\
\text { GB) }\end{array}$ & Sterling Winthrop (USA) ${ }^{(3)}$ & SmithKline Beecham & 2.925 \\
\hline & Johnson\&Johnson (USA) & $\begin{array}{l}\text { Eastman Kodak Clinical } \\
\text { (USA) }\end{array}$ & Johnson \&Johnson & 1.009 \\
\hline & Ciba (Switzerland) & Chiron (USA) & Ciba & 0.616 \\
\hline & Eli Lilly (USA) & PCS Health Systems (USA) & Eli Lilly & 4 \\
\hline & Sandoz (Switzerland) & Gerber (USA) & Sandoz & $21^{(6)}$ \\
\hline \multirow{4}{*}{1995} & Glaxo (GB) & Wellcome (GB) & Glaxo Wellcome & 14.285 \\
\hline & Hoechst (Germany) & Marion Merrel Dow (USA) & $\begin{array}{l}\text { Hoechst Marion Rous- } \\
\text { sel }\end{array}$ & 7.121 \\
\hline & Pharmacia AB (Sweden) & Upjohn (USA) & Pharmacia\& Upjohn & merger \\
\hline & Rhône-Poulenc Rorer (France) & Fisons (GB) & Rhône-Poulenc Rorer & 2.888 \\
\hline
\end{tabular}


TABLE 7. (continued).

\begin{tabular}{|c|c|c|c|c|}
\hline \multicolumn{2}{|r|}{ Company 1} & Company 2 & New identity & Value ${ }^{(5)}$ \\
\hline 1996 & Ciba-Geigy (Switzerland) & Sandoz (Switzerland) & Novartis & merger \\
\hline 1997 & Roche (Switzerland) & Boehringer Mannheim (Ger) & Roche & n.d \\
\hline \multirow{3}{*}{1998} & Astra (Sweden) & Zeneca (GB) & AstraZeneca & merger \\
\hline & Hoechst (Germany) & Rhône-Poulenc (France) & Aventis & merger \\
\hline & Sanofi (France) & Synthélabo (France) & Sanofi- Synthélabo & merger \\
\hline \multirow{4}{*}{1999} & Celltech Chiroscience (GB) & Medeva (GB) & Celltech Chiroscience & 0.9 \\
\hline & $\begin{array}{l}\text { Roberts Pharmaceutical } \\
\text { (USA) }\end{array}$ & Shire Pharmaceuticals (GB) & Shire Pharmaceuticals & 1 \\
\hline & Millennium (USA) & LeukoSite (USA) & Millennium & 0.635 \\
\hline & Monsanto (USA) & $\begin{array}{l}\text { Pharmacia\&Upjohn (Swe/ } \\
\text { USA) }\end{array}$ & Pharmacia Corporation & merger \\
\hline \multirow{2}{*}{2000} & GlaxoWellcome (GB) & SmithKline Beecham (GB) & GlaxoSmithKline & merger \\
\hline & Pfizer (USA) & Warner-Lambert (USA) & Pfizer & 91.4 \\
\hline
\end{tabular}

(1) Pharmaceutical division only; (2) Prescription drugs; ${ }^{(3)}$ OTC division only; ${ }^{(4)}$ AHP: American Home Products ; ${ }^{(5)}$ In billions of US dollars; ${ }^{(6)}$ In billions of French francs.

Source: Hamdouch and Depret (2000).

as a hybrid, transitory and discontinuous mode for the discovery and coordination of new ex post exploitable industrial opportunities by the partners. Thus, once the result of cooperation is known (i.e. lifted uncertainty), economic coordination must be analysed through the standard market/organization dichotomy.

In reality, generally, as in the pharmaceutical industry (Hamdouch, 1998; Depret, 1999), cooperation is a form of interfirm interaction of both a general - as it is practiced by all pharmaceutical companies and all mature biotech companies, for all the links in the value chain - and a permanent nature, as all pharmaceutical companies have been or are, at present, involved in at least one alliance or partnership ${ }^{18}$.

\footnotetext{
${ }^{18}$ Based on available data (Windhover's Pharmaceutical Strategic Alliances 2000, in PhRmA, 2000), three major phases have been identified in the evolution of many strategic alliances in the pharmaceutical industry since 1986: a regular increase in 1986 (121 alliances) until 1990-91 (respectively 319 and 324 operations); strong growth in 1992 (428 alliances) and stabilisation at a high level up to 1995 (over 445 alliances on average per year); and finally, a high increase in 1996 (577 operations) and 1997-98 (700 and 712 operations respectively). An in-depth analysis of the content of the alliances shows that $(i)$ at each period, the number of alliances increased convexly with respect to the number of M\&A's, thus, invalidating the idea according to which cooperation and integration-concentration are totally alternative modes; and (ii) that alliances change through time. In this way, we can see a gradual change from upstream cooperation to intermediary and more and more downstream cooperation, which explains above all the growing ability of biotechnology to conduct co-development and co-marketing programmes with large pharmaceutical companies as well as amongst themselves.
} 
According to several recent studies, the thirty leading world pharmaceutical companies are all involved on average in forty cooperation operations (Andersen Consulting, 1997), representing from 10 to $20 \%$ of research budgets (PriceWaterhouse Coopers, 1999 ) and 20 to $40 \%$ of income (Boston Consulting Group, 1999). Furthermore, it is to be noted that while nearly seven research programmes out of ten were carried out internally by pharmaceutical groups in 1995, research contracts and partnerships should represent nearly 45\% of total programmes in 2005 (Boston Consulting Group, 1999). Finally, while the share of research conducted externally in the total R\&D budget varies considerably according to the pharmaceutical company, this ratio is expected to quickly exceed $25 \%$, reaching about 30 to $40 \%$ in the years to come (see Eurasanté, 1999b, and supra Tab. 5).

This data thus moves away from the problematic of interfirm relations proposed by the transaction cost theory as, while R\&D activity in the pharmaceutical industry is highly specific in essence, pharmaceutical companies do not hesitate to outsource or to carry out a rather substantial part of work in a cooperative manner (see Fig. 1 and Eurasanté, 1999b).

In fact, the current increase in capitalistic mergers in the pharmaceutical industry can mainly be explained by technological change and market globalization and, more precisely, by the persistent and amplified uncertainty with which pharmaceutical companies have been confronted. Thus, the increase in size permitted by M\&A seems to be less of an objective in itself than a means for seeking new partners so as to master the competitive regime brought about by the structural changes in progress in this industry (Depret and Hamdouch, 2000a).

\subsection{Changing modes of interaction}

While the modes of interfirm interaction are diverse and multidimensional, they also evolve, partly due to the strong uncertainty and irreversibility that structurally make up the drug industry all along its value chain ${ }^{19}$, and, on the other hand, to the strategies adopted by pharmaceutical companies so as to adapt to new rules within a context of "structural uncertainty" (Langlois, 1984).

Firms must thus use all the strategic tools available, that they combine differently from their competitors and in a way that evolves in time, as generally speaking, there is no "one best way" when it comes to organization and strategy. As a result, four periods can be observed as regards the evolution of relations between pharmaceutical and biotech companies (see Box 1).

\footnotetext{
${ }^{19}$ In this industry, uncertainty relates to the nature of the request, legislation, techniques, know-how and modes of R\&D organization, as well as to the ex ante evaluation of promising projects and the future possibilities of strategic interaction. They are reinforced by the more or less strong situations of irreversibility, beyond some stages of the innovation process and sale (target discovery, patenting a molecule, authorization to launch a new product on the market, or the imposed or decided withdrawal (switch) from the market, etc. See Hamdouch and Perrochon (1999a).
} 


\section{Box 1. The four stages of relations between the pharmaceutical industry and bio-} technology.

From the early 70 's to the mid- 80 's, we have been witnessing a "wait and see" attitude that is all the same attentive to pharmaceutical companies with respect to the biotechnology that are developing essentially in an isolated manner.

In the second half of the 80 's, pharmaceutical companies became aware of the true cognitive potential of biotechnology (that advance "technically" and whose sales forecasts became more realistic) and then jumped into a frenzy of alliances, capitalistic mergers and research internalization.

In the 90's, products from biotechnology became more usual. Focus was then placed on sales, and property rights became a stake. We thus witnessed re-specialization and re-focussing strategies, and the formation of close ties with biotech companies.

Today, the new "rules" of the game are beginning to be felt. We then observe a movement, slow perhaps but clearly perceptible, of companies becoming gradually autonomous with respect to pharmaceutical companies or, more precisely, of the interdependence between partners that are able to "live" separately but prefer to interact closely as this solution is quicker and more effective for the development and sale of new products.

Sources: Raugel, 1993; Sharp et al., 1994; Maupertuis, 1997; Delapierre et al., 1998; Depret, 1999; Depret and Hamdouch, 2000b.

definitively stops, or is finally renegotiated (Hamdouch and Perrochon, 1999a). But, on the other hand, this switch does not make cooperation "in general" a hybrid and temporary form of interfirm relations. On the contrary, it constitutes a permanent and substantial form of interaction between rival and/or complementary firms (see Hamdouch, 1998). It is thus distinguished from its particular modes of operation (alliances, agreements and partnerships), which are necessarily transitory and discontinuous (Depret, 1999).

\subsection{Interwoven modes of interfirm interaction}

The exploration and exploitation, at the highest and with the lowest cost, of the complex process of pharmaceutical innovation, as well as management of the uncertainty/irreversibility pair, are generally only possible by adopting "sequential strategies combining movements of commitment or, on the contrary, those of waiting, experimentation, consolidation or redeployment, or even withdrawal" (Hamdouch and Perrochon, 1999a). This also above all includes the necessary complex combination of the different modes of interfirm interaction, as shown in the example of the agreement signed between the American pharmaceutical company Abbott and the French biotech company Genset. This agreement is indeed characterized by the combination of a "dose" of cooperation (by its complementary nature), of an equity participation (Abbott in Genset), and of maintaining a true rivalry between both partners (that basically remain competitors 
within the market ${ }^{20}$ ). It, in this way, clearly demonstrates the consubstantial nature of the different modes of interfirm interaction (Hamdouch, 1998) and characterizes typically what we call a coalition.

In fact, beyond their diversity, and their interweaving and basically changing nature, the modes of interfirm interaction in the pharmaceutical industry are today characterized by the emergence of highly original competitive and cooperative combinations, particularly in the form of highly varied bilateral or multilateral coalitions and of firm networks (or coalition networks).

\section{Coalitions and networks: towards a radical reconfiguration of interfirm relations in the pharmaceutical industry}

Faced with the problems presented by the development of new products and changes in market rules, the traditional shapes of competition and interfirm cooperation are losing much of their pertinence. Hybrid and more collective forms of interaction such as coalitions and networks are becoming the favoured modes of interaction in this type of industry, as they make up the essential vectors of configuration of the dynamics of actual competition and of the future structuring of organizations and markets (Aoki, 1990; Hagedoorn and Schakenraad, 1994; Kotabe and Swan, 1995; Hamdouch, 1998, 2000). Within a context of increasingly globalized competition, each firm must therefore build and exercise (or simply belong to) coalitions and networks sufficiently powerful and durable so as to stay - and possibly dominate - in the innovation race and the struggle for market shares.

\subsection{The nature, characteristics and shapes of coalitions and networks in the pharmaceutical industry}

The increasing number of uses of the notions of coalition and network gives them a polysemic nature that is particularly diversified, thus turning them into true "interdisciplinary metaphors" (de Bresson and Amesse, 1991). They must be defined correctly so as to discern their main characteristics and shapes in the case of the pharmaceutical industry.

\footnotetext{
${ }^{20}$ By way of this agreement, signed in 1997, Genset undertakes to identify the markers and genes associated with the response to treatments proposed by Abbott (we speak of "pharmacogenomics"). The results will then be used by Abbott, which will develop, produce and sell the resulting diagnostics systems. In return, Abbott undertakes to comply with the four following obligations: to finance company research by Genset for a period of eighteen months; to make payments according to the progress of programmes (milestones); to pay a fee on the sale of pharmacogenomic diagnostics; to enter into immediate shareholding of $5 \%$ of the capital of Genset, as well as a future option in additional shareholding (Hamdouch and Depret, 2000). It is to be noted that this principle has once again been selected by the two partners within the scope of an agreement signed in March 2000 in the field of genetic diagnostics of manic-depressive psychosis and Type II diabetes.
} 


\subsubsection{Firm coalitions}

Based on the theory of games (see Von Neumann and Morgenstern, 1944), the notion of coalition has been covered in many works in areas such as sociology, politics and economy (Lemieux, 1998). In Industrial Economics, coalitions are often confused with the notions of strategic alliance, agreement or even interfirm cooperation ${ }^{21}$. By borrowing from the fields of sociology ${ }^{22}$ and economics, we offer a definition that is broad enough to be able to take account of the variety of interfirm relations and the multiple combinations of forms of interaction observed in the pharmaceutical industry. Coalition designates then here bilateral or multilateral relations for the common achievement of a given activity, through the control, exchange or sharing of information, know-how, knowledge, as well as (intermediary or finished) products and/or capital.

Within this scope, three major types of coalitions can be observed (Hamdouch, 2000), as illustrated clearly in the current dynamics of the pharmaceutical industry:

- Vertical coalitions (vertical partnerships in research, clinical development, production or sale, and, alternatively, vertical integration operations), initiated by one or several firms or structures that are complementary or potentially complementary;

- Horizontal coalitions, the most commonly used, formed by competitive or potentially competitive firms, against rival firms and against suppliers, clients or producers of complementary goods. We speak here of strategic alliances upstream (R\&D alliances), intermediary (co-development, co-production) and/or downstream (co-promotion, comarketing, product outsourcing), or, alternatively, of M\&A's or equity participations (crossed or not);

- Transversal coalitions, more rarely used, which bring together firms from different sectors of businesses that are (actually or potentially) involved in the preparation and sale of goods-systems ${ }^{23}$.

\footnotetext{
${ }^{21}$ By reminding of its contribution to the analysis of coalitions (Porter and Fuller, 1986), Porter (1993) thus speaks almost indifferently of strategic alliance and coalition (pp. 72 and 591), of interfirm understanding (pp. 72) or of interfirm cooperation (pp. 648). Within this scope, coalition is defined as a long-term agreement (between two or several companies working in the same industry), going beyond simple commercial transactions (without however being a merger), mainly in the form of joint ventures, licence exploitation agreements or supply agreements, but finally as way to take on a competitive advantage.

${ }^{22}$ In sociology, the notion of coalition applies to relations between all types of organizations. It defines a concerted and temporary group of individual or collective players that together exercise relations of cooperation and conflict, and seek, by structuring the appropriate power, to dominate their opponents in order to obtain more significant advantages than if they were not part of the coalition (Lemieux, 1998).

${ }^{23}$ For example, we think of coalitions between biotech companies and microelectronics or computer companies (Motorola, IBM, Hewlett-Packard, MIT, Perkin Elmer, Hitachi, etc.) or between pharmaceutical firms and companies specialized in the e-business (Healthon, PlanetRx.com, Drugstore.com, etc.).
} 


\subsubsection{Interfirm networks}

At the same time, the network is generally considered in economic literature as either:

- a mode of coordination (Béjean and Gadreau, 1997) or organization of economic activity (Joly and Mangematin, 1995; Dufourt, 1995) and interfirm relations (Massard, 1997), intermediate between the market and hierarchy ${ }^{24}$;

- or a collective entity (Joly and Mangematin, 1995), specific and organized (Dufourt, 1995), whose behaviour cannot be reduced to that of some of its components (Joly and Mangematin, 1995), and whose analysis cannot be reduced to that of the degradation of the polar forms of organization, which are market and organization (Dufourt, $1995)^{25}$.

In reality, this distinction is not always evident, as shown in the case of interfirm pharmaceutical networks. An interfirm network must thus be considered as a form of interfirm interaction enabling the coordination of activities and as an "institutional creation" (Dufourt, 1995; Lazega, 1996).

More precisely, in the pharmaceutical industry, interfirm networks correspond to a form of organization of the productive process that is specific, dynamic, generalized and relatively continuous. It brings together a group of heterogeneous players ${ }^{26}$ (Callon, 1991), with know-how and/or specific and/or complementary resources, interconnected by informational, economic, financial and/or human links ${ }^{27}$ so as to meet objectives that are above all of an individual nature (Depret, 1999) ${ }^{28}$. The players in a network are mutually interdependent within the scope of a generally long and costly innovation process. This interdependence then determines the stability and evolution

\footnotetext{
${ }^{24}$ This conception of an industrial, technological or technical-economic network has been strongly inspired by the theoretical new-institutional framework (see Hamdouch and Depret, 2000). For a discussion and many applied approaches, see among others: Thorelli (1986); Powell (1990); Aoki (1991); Callon (1991, 1994); Imai and Baba (1991); Maillat et al. (1991); Planque (1991); Axelsson and Easton (1992); Dufourt (1995); Freeman (1995); Joly and Mangematin (1995); Béjean and Gadreau (1997).

${ }^{25}$ The network must thus be considered as a whole, as a "dual form of organization" (Joly and Mangematin, 1995) and as a producer of standards and regulations (Dufourt, 1995).

${ }^{26}$ Here, we speak of pharmaceutical companies, biotech companies, service companies, universities, academic or public research centres, foundations, etc.

${ }^{27}$ Callon (1991) speaks of "intermediaries" that he defines as all that revolves around the players (codified knowledge, technical objects, currency, skilled individuals and know-how) and that constitute the form and content of relations that are set up between them (Callon, 1999).

${ }^{28}$ Synthetically speaking, through the network, partners search (i) complementary activities (Richardson, 1972), assets (Dosi et al., 1990; Garrette and Dussauge, 1991) and/or external (Hakanson and Johanson; 1988) and specific resources (Bouabdallah and Dufourt, 1994); (ii) synergy between relatively specialized (Guilhon and Gianfaldoni, 1990) and operationally autonomous partners (Perrin, 1991), within a network whose management is codified (Maillat et al., 1991), collective and interactive (Perrin, 1991); (iii) the will to reduce uncertainty being linked to decision-making in a complex, transitory world that is constantly changing (Cook, 1977; Pfeffer and Salancik, 1978); (iv) conveying information and fragmented knowledge (know-how) that can be at the origin of new competence and new knowledge.
} 
of the network ${ }^{29}$. In this way, on the one hand, each partner is relatively in need of the information of other partners. On the other hand, very few participants are able to break the bonds that have been established or they lose all credibility when seeking new partners (Depret, 1999). A network must therefore be understood over a period of time. Indeed, while in the short term the network can be justified by a functional rationale of activity connexion, in the long term, the notion of relations between players comes into play (Filippi et al., 1996), based on technological and relational learning processes (De Bresson and Amesse, 1991; Bidault, 1993; Cohendet and Llerena, 1993), and on confidence and reputation (Callon, 1991; Granovetter, 1985; Koenig and van Wijk, 1992; Joly and Mangematin, 1995; Massard, 1997; Depret, 1999).

The nature of interfirm relations in the drug industry relies on four key dimensions. The first one is linked to the therapeutic nature of the network. Indeed, coalitions generally cover a wide therapeutic spectrum, ranging for example from the fight against cardiovascular diseases ${ }^{30}$ to more rare connections specialized in "orphan diseases" (see Depret and Hamdouch, 2000c). Networks thus tend to regroup firms or research centres conducting complementary research programmes, i.e. directed toward common or similar pathologies.

The second dimension is related to the technology used. With the emergence of a new paradigm for pharmaceutical innovation, this dimension is destined to become increasingly important. In matters of biotechnology, DNA-based therapies can be distinguished from technological platforms (see supra $\S 2.1$.). While the first ones are substituted for the final product, the second ones are complete so as to improve the innovation process. Technological coalitions thus aim to complete therapeutic coalitions ${ }^{31}$.

The third dimension depends on the degree of market maturity. Indeed, the more mature the market is, the easier it will be for a firm to approach it individually. On the contrary, collective strategies and coalitions tend to increase when the market in question is insufficiently mature (biochips, proteomics, pharmacogenomics, gene therapy, etc.), or

\footnotetext{
${ }^{29}$ It is said that a network is both stable and changing (Guilhon and Gianfaldoni, 1990; Maillat et al., 1991) when the players that form it cannot be changed, replaced, moved, without harming its uniqueness, flexibility and malleability, or without questioning its ability for action and adaptation to outer stimuli (Rivière, 1997). This is all the more true since, in the case of the pharmaceutical industry, the network is guided by the same objective, that of innovation. Yet the (pharmaceutical) innovation process is not linear in nature (Callon, 1994). Consequently, a change in the network is closely linked to the project of innovation (Maillat $e$ al., 1991). The network is built and transformed (Guillon and Gianfaldoni, 1990; Massard, 1997) according to the constraints with which the players are confronted in their approach to innovation. It therefore takes on different forms in time. Its main elements change and are organized differently according to a recurrent process (Guilhon and Gianfaldoni, 1990), but the network globally maintains its identity.

${ }^{30}$ To cite an example, the Swiss company Roche has had, for several years now, a network of alliances centred around American (Myriad Genetics, Centocor, EnzyMed, Focal, American Biogenetic Sciences, CV Therapeutics, Scios) and Canadian biotech companies (Nortran Pharmaceuticals), either alone or through Syntex and Genentech, its autonomous biotech subsidiaries.

${ }^{31}$ Here, we refer to the Gencell gene therapy network (see Box 2) as well as, to cite an example, the American Merck network in combinatory chemistry, for several years centred on pharmaceutical (Abbott, Aventis, DuPont, Merck KGaA,, Astra and Sumitomo) and biotech companies (Argonaut Technologies, Ariad Pharmaceuticals, Genetics Institute, Dyax, 3-Dimensional Pharmaceuticals, EnzyMed, ISIS Pharmaceuticals and Axys Pharmaceuticals).
} 
hardly accessible (China, India, etc.). Forming coalitions and networks thus enables pharmaceutical companies to solve or attenuate the dilemma of tight/broad specialization (Depret, 1999) within the framework of strategies for renewing portfolios, going around barriers as regards entry or strategic watch. New therapeutic and/or geographic markets thus become more accessible to a greater number of firms.

Finally, the fourth dimension is related to geographically locating partners. While networks are generally bringing together partners that are relatively close geographically (Genet, 1997), more "complex" networks are also made up of partners seeking to benefit by the conditions offered as a result of the partners' differences in economic, scientific and statutory environments (see supra $§ 1.2$ ).

\subsubsection{The link between coalition and network in the pharmaceutical industry}

The notions of coalition and network come at least partially together. Indeed, coalitions naturally aim to take on a reticular form. The coalition-network link is thus brought to come about in two complementary ways: reticular coalition (coordination in a network of specific activities of individual firms) in which the notions of network and coalition are confused, and the coalescent network (coordinated set of different coalitions ${ }^{32}$ whose members wish to benefit by the advantages of reticular organization).

Within this framework, it is possible to see today's pharmaceutical industry as a new industrial organization characterised by an interconnection of coalitions and networks in which each pharmaceutical company seeks to develop and defend the network(s) to which it belongs. A pharmaceutical company forms coalitions with other pharmaceutical companies, as well as with biotech companies, service providers and research centres, which in turn are forming coalitions with pharmaceutical companies, biotech companies, service providers, research centres, etc.

\subsection{Outline of a taxonomy of networks in the pharmaceutical industry}

In this industry, networks correspond to four basic configurations, whose varied forms and examples are shown in Figures 2 and 3.

\subsubsection{Coordinated networks}

The coordinated network is made up of several bilateral coalitions between different partners working on common themes or issues. Three different types of coordinated networks can be observed: vertical, when a pharmaceutical company forms a coalition with several biotech companies, service companies and/or academic research structures ${ }^{33}$;

\footnotetext{
${ }^{32}$ In fact, two firms can very well not be linked by a single coalition, while they are members of the same network. For this, the two firms need only to have a common partner.

${ }^{33}$ To cite an example, the American company Bristol Myers Squibb has had a network of alliances for several years now specialized in the fight against cancer centred around academic research centres and essential American biotech companies (Millennium Predictive Medicine, Somatix, Oxigene, Liposome, Seattle Genetics, Cydex, Neose, Research Triangle Institute, Cytoclonal Pharmaceutics, Genzyme Transgenics Genetic Therapy, University of Texas, Progenics Pharmaceuticals, Supergen, EntreMed, Somatix Therapy), as well as Canadian (University of Manitoba), Spanish (PharmaMar), Swedish (Karolinska Institute), British (Chiroscience) and Japanese (Taiho) biotech firms.
} 

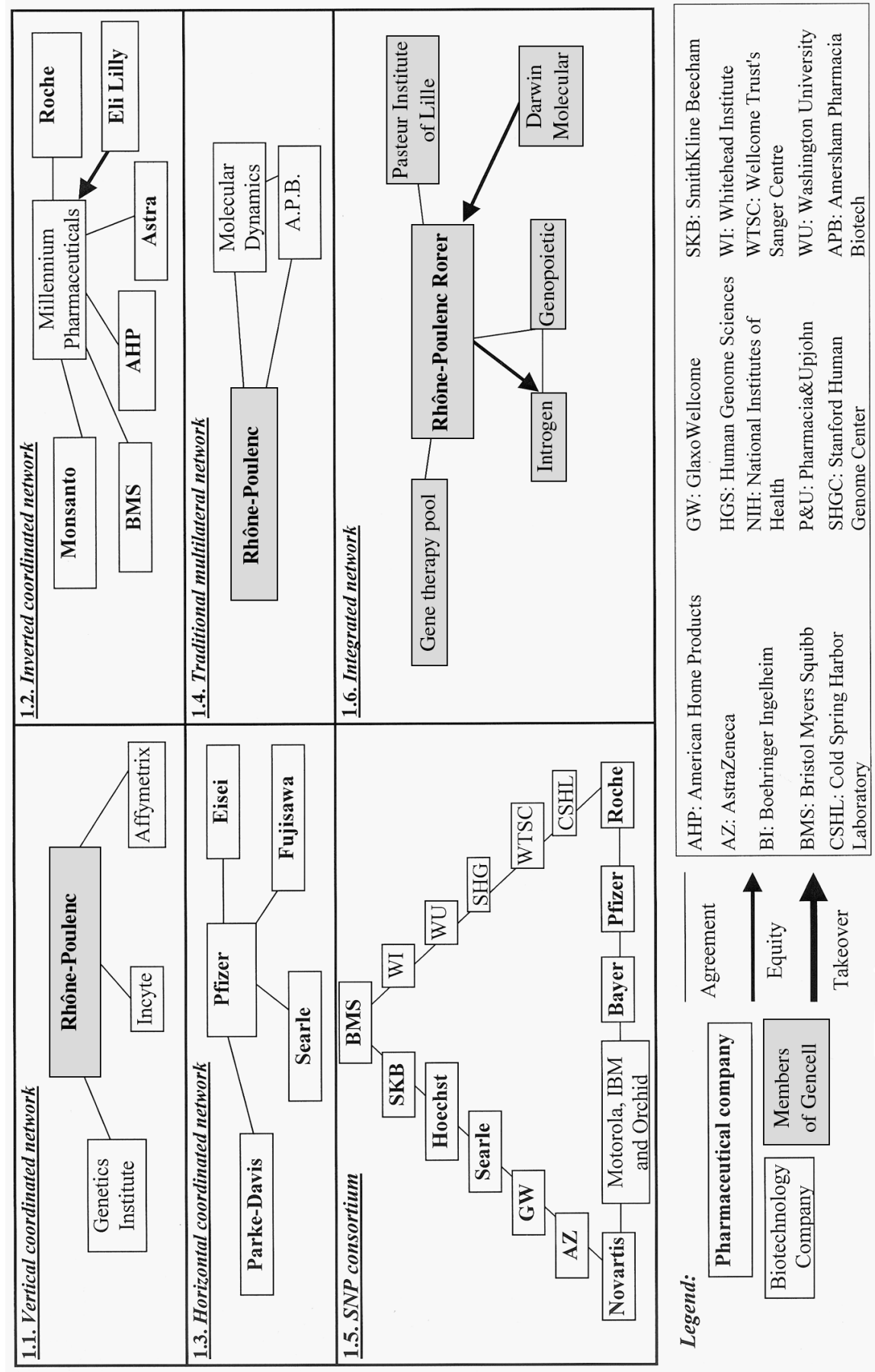

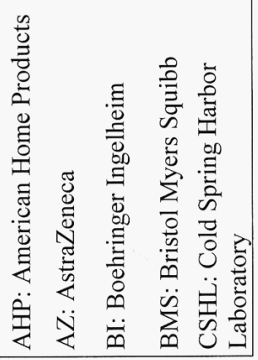

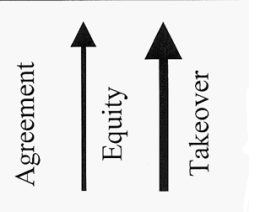

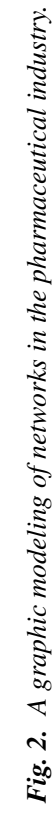

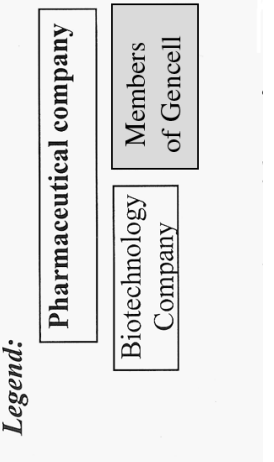




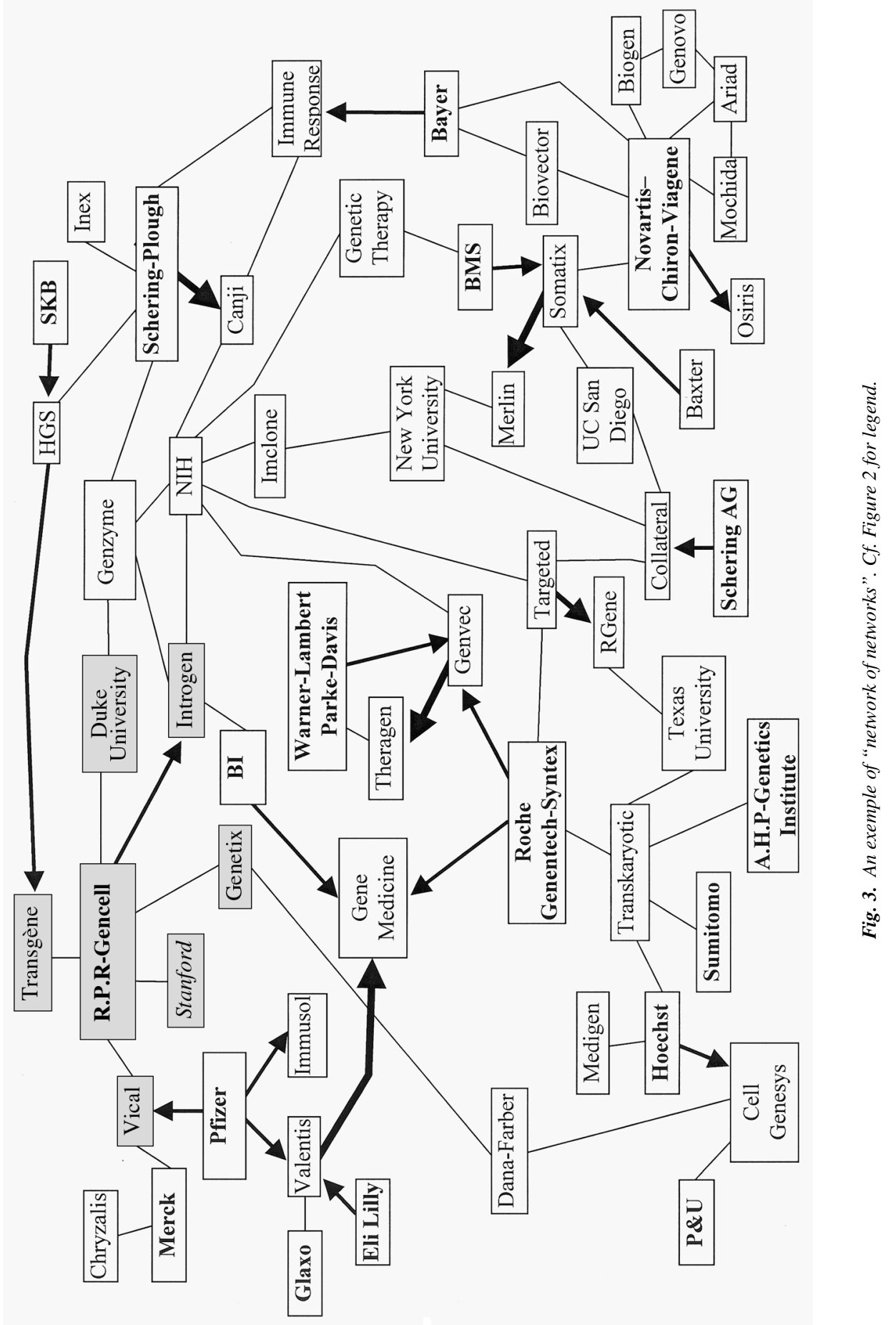


inverted, when several pharmaceutical companies form a coalition with a biotech company ${ }^{34}$, a service company (see Eurasanté, 1999b) or an academic research structure (see Cassier, 1995); and finally horizontal, when several pharmaceutical companies (or biotech companies) form coalitions together ${ }^{35}$.

\subsubsection{Multilateral networks}

The multilateral network is made up of several partners, generally without a single or central coordinator. This includes the traditional multilateral network - binding three or four partners to a new theme or to one that is not promising enough to be part of internal research ${ }^{36}$-, the collective consortium ( between several partners ${ }^{37}$ that exchange information or coordinate their R\&D activity together (such as SNP ${ }^{38}$; see Fig. 2) -, and the industry organization network (see supra $\S 3.1$.).

\subsubsection{Integrated networks}

The integrated network is centred round a core and satellites (see the "gene therapy pool" for example of Rhône-Poulenc-Rorer (RPR) represented in Fig. 2). Here, collaboration is not limited to only the complementary nature of competences. The central company of a network in fact sets into motion a dynamics for mutual learning between the members so that the product of interaction cannot be obtained (as quickly, in most cases) if the partners are satisfied with only exchanging (vertically or bilaterally) their competences, know-how, techniques, etc. (Depret, 1999).

\subsubsection{The network of networks}

Assembling this reticular puzzle into a cooperative network is ever more difficult to decode, as the networks are multiplying and becoming interwoven (for a simplified

\footnotetext{
${ }^{34}$ In this way, the French biotech company Genset has set up a network of alliances (with Sanofi/Synthelabo, Pharmacia\&Upjohn, Janssen (Johnson\&Johnson), Wyeth-Ayerst (American Home Products) and Abbott) so as to broaden competence, therapeutically - while working in different areas (Type II diabetes, manic-depressive psychosis, schizophrenia, etc. - and technologically, by developing programmes of pharmacogenomics, identification and genetic cloning, diagnostics and vaccination.

${ }^{35}$ In the first case, we are thinking of the network set up by the American company Pfizer with Parke-Davis (Warner-Lambert), Searle (Monsanto), Eisei and Fujisawa, so as to co-promote Lipitor ${ }^{\odot}$ and Celebrex ${ }^{\odot}$, as well as to work with the Japanese in the areas of Alzheimer's disease, cancer, and osteoporosis (see Fig. 2). In the second case, the network in gene therapy was made up of, in the 90's of Genetic Therapy, Targeted Genetics, GenVec, Canji, Introgen, Genzyme and Inclone Systems centred round the American National Institutes of Health (Depret and Hamdouch, 2000c), as one example.

${ }^{36}$ For example, we are speaking of the alliance formed in May 1998 by American Home Products, Molecular Dynamics and Amersham Pharmacia Biotech in the field of DNA chips (biochips).

${ }^{37}$ Generally speaking, the partners of the research consortium specialize within sub-programmes. For example, the European consortium on lipases was subdivided into five sub-programmes, thus forming as many coalitions (see Cassier, 1998; Cassier and Foray, 1999).

${ }^{38}$ The latter is made up of eleven bio-pharmaceutical companies, five American and British research centres and three computer and electronic companies (see Fig. 2) so as to prepare a detailed map of the genome using natural markers known as "snips" (Rosier, 1999).
} 
example, see Fig. 3). We then speak of a cooperative network, i.e. a network of coordinated, multilateral and integrated networks that interpenetrate (Depret, 1999). For example, $R P R$ today is involved in over one hundred and seventy coalitions, more than one-quarter of which are considered as major ( $R P R 1999$ Activity Report and diverse data taken from Recap Database). In addition to the coalitions forming the Gencell network (see Box 2), $R P R$ has in fact signed agreements in different fields, on different links of the value chain and in different reticular organizations.

\section{The emergence of a new competitive dynamics}

The quick changes in interfirm relations towards increased structuring into coalitions and networks are demonstrated by an in-depth reconfiguration of the competitive process. The competitive game seems in this way to be extended to new "zones" of rivalry outside the market, moving from a strict inter-individual level towards more and more "collective" interactions within a play of intra and inter coalitions and networks of firms. The process for the setting up and evolution of these hybrid structures, which are both competitive and cooperative as a result, represent the major strategic stakes for bio-pharmaceutical companies.

Thus, analytically speaking, it is possible to observe at least four levels of competitive and cooperative games implied in the reticular rationale: $(i)$ formation of coalitions and networks through a rationale of potential partner's pre-emption; (ii) consolidation of coalitions and attraction of new partners; (iii) rivalry within the coalitions and networks formed, more or less consolidated; (iv) competition between coalitions and networks. Here, we are just presenting an outline of the content of these games through the current changes in the pharmaceutical industry, a more general analysis of the rationale for forming coalitions being part of more formal studies, particularly in the case of standardization processes (see Katz and Shapiro, 1994; Foray, 1995; Hamdouch, 2000; etc.). The example of the network of networks in gene therapy illustrates the different types of games centred round the reticular approach (see Fig. 3 and Box 2).

\subsection{The "race" towards forming coalitions and networks}

The first game level, highly upstream the competition process in markets, involves different firms in a sort of "race" towards forming coalitions, enabling each one to pre-empt the partners that are necessary for its network. In this way, each new coalition aims to make its network more consistent and effective, therapeutically, technologically and geographically.

The pre-emptive strategy, prevailing in the formation of coalitions and networks results from the fact that the "stock" of strategically decisive potential partners is relatively restricted. This strategy covers three major dimensions:

- The first-mover is in a position to attract the best partners. By doing so, it reduces (in number and often also in "quality") the stock of potential partners for coalitions and networks that can form successive followers. Forming coalitions and networks has 
therefore a formative and locking character, above all when the principle of exclusivity ${ }^{39}$ plays a major part (see Hamdouch, 2000);

- The first coalitions and networks to be formed, and which are organized more rapidly at the operational level, become the most attractive ones for potential partners not yet united. The successive members of a coalition or network thus bring about a cumulative process of an "increasing coalition returns" type, a bit in the image of the "increasing adoption returns" principle of a technology formalized by Arthur (1988);

- Finally, the early formation of quickly structured coalitions or networks may discourage the formation of alternative coalitions or networks if the followers feel that the game is bound to be lost. In a looser form, this configuration resembles the $\varepsilon$-pre-emption strategy described in some models of patent race (see particularly Dasgupta and Stiglitz, 1980). However, this can, inversely, incite followers to strengthen their efforts so as to join forces in an attempt to catch up and possibly exceed the leading coalition (leapfrogging strategy described by Fudenberg et al., 1983).

This notion of competitive coalition can be illustrated by the formation of Gencell (see Fig. 3 and Box 2). This network is mainly centred on the central nervous system, cardiovascular diseases and oncology. The partners are either specialized in one predetermined therapeutic direction, or integrated by their specific competence and know-how in gene therapy. Gencell thus enables $R P R$ not only to have access to new competences and know-how - which are sources of crossed fertilization and significant technological and industrial synergy -, and to benefit by the conditions offered by the competitive distortions of the different economic, scientific, statutory environments of the partners, but also to create a true mobility barrier, by reducing the number of potential partners for its competitors, and by gaining precious time in the innovation race.

\subsection{The "race" for reticular consolidation}

The second level of the game can be illustrated by strategies of attraction-confinement of the pre-empted partners or of those likely to reinforce the network. This is a question of attracting companies still belonging to other networks (consolidation strategy) and, symmetrically, defending oneself against the risk of having partners flee to other competitive networks (stabilization strategy). This power of attraction-confinement on the part of a firm will depend on the quality and variety of its network, of the partner's degree of dependence with respect to the reticular core, and of the strategic nature of the partner.

This game configuration can be illustrated by the recent confrontation between the American pharmaceutical companies Pfizer and American Home Products (AHP) over the control of Warner-Lambert $(W L)$. Thus, as $A H P$ and $W L$ revealed the terms of their merger, Pfizer announced its will to take over $W L$, for an exchange of shares (of a value of 82.4 billion dollars). By overbidding by over $14 \%$ with respect $A H P$ 's bid, the manu-

\footnotetext{
${ }^{39}$ When a firm enters into a coalition, it is generally prohibited for it, at least for a certain period, to take part in an alternative coalition in the same area (existence of contractual and or irreversible financial shortmedium-term commitments, difficulties as regards organization in terms of managing several programmes at the same time, etc.).
} 


\section{Box 2. The strategic games within and around the Gencell network.}

Formed in 1994 by Rhône-Poulenc Rorer (RPR), Gencell is an integrated network of at least thirty-four partners federated around gene therapy and directed towards therapeutic areas within the scope of its specialization (Staropoli, 1998; Rhône-Poulenc Rorer, 1998). Gencell plays a major role in the formation of the $R P R$ coalition network and is even able to illustrate the link between the different intra or inter-reticular games.

(i) The formation of coalitions and networks and the pre-emption of the most strategic partners: before 1994, RPR took part in many French and European biotechnology programmes, such as BioAvenir, for which it was the coordinator (Staropoli, 1998). This experience encouraged technological, therapeutic and relational synergies, reduced any uncertainty linked to gene therapy and participated in making $R P R$ 's reputation. All these factors naturally encouraged the creation of Gencell, as the main members of BioAvenir joined in (CNRS, Pasteur Institute, Gustave Roussy Institute, etc.).

(ii) Competitive coalitions and the games of attraction-confinement of pre-empted partners or those likely to strengthen the network: these games can be illustrated by the way the members of the network interact with other networks. Therefore, of all the Gencell members, only eight have succeeded in forming coalitions with other partners, within the "sub-network" (Vical, Transgène) and/or outside with other "sub-networks" (Transgène, Duke University, Vical, Genetix Pharmaceuticals, Stanford, Introgen Therapeutics, Baylor Medical Center, Johns Hopkins University). While the analysis has been extended to areas not directly related to gene therapy, the partners of RPR-Gencell can be placed into at least three categories: those who did not wish to form significant coalitions outside Gencell and gene therapy (Genetix Pharmaceuticals, Genopoietic, Supratek, Transgène, University Louis Pasteur of Strasbourg, Virogenetics, IntraImmune Therapies, NARA Institute of Technology, Xenon Bioresearch, University of Cagliari); those who have succeeded in forming limited number of coalitions (CNRS, Darwin Molecular, Endocyte, Enzon, Généthon, Curie Institute, Gustave Roussy Institute, Introgen Therapeutics, Lawrence Berkeley Laboratory, Oxford BioMedica, Vical, St Elizabeth's Medical Center, Bichat Hospital of Paris, Biosense); and finally, those who have succeeded in moving away from the "centripetal force" of the network (Duke University, Pasteur Institute, LXR Biotechnology, Oncormed, Stanford, University of British Columbia, University of Alabama, BASF, Sequus (Alza), Baylor Medical Center, John Hopkins University).

(iii) Intra-reticular competition is also as present in the scope of Gencell, even if, in this case, it does not concern a fight for leadership, while that of $R P R$ is in essence practically indisputable. The fact that the partners of RPR-Gencell are either specialized in a predetermined therapeutic direction (cardiovascular diseases, diseases of the central nervous system, oncology), or, on the contrary, integrated for their own competence and specific know-how in gene therapy, in fact adds a dose of competition in the coordination of the network since the areas of research are relatively convergent.

(iv) When rivalry within a network is quite localized, the competition between networks appears to be stronger. Indeed, the study of the different types of interaction taking place in gene therapy enables light to be shed on four "sub-networks" that are relatively consistent and competitive, inasmuch as the members of a "sub-network" tend to remain faithful to it (see Fig. 3):

- In the northwest quarter of the network of networks in gene therapy, the sub-network is dominated by $R P R$ and its partners;

- In the northeast quarter, the sub-network is largely made up of biotech companies that interact around "pivot firms" (NIH, Genzyme, Introgen), and in parallel form, for the most part "buffer firms" between different sub-networks (Introgen, Targeted, New York University, Immune Response, Duke University, Genetic Therapy). This sub-network can then be considered as complementary to the other sub-networks.

- In the southeast quarter, the sub-network is dominated by Novartis (and its subsidiaries) around a great number of biotech companies.

- Finally, in the southwest quarter, the biotechnology company Transkaryotic succeeds in federating biotech companies but also pharmaceutical companies such as Roche, $P \& U, A H P$ and Hoechst. However, it is to be noted that the latter sub-network is the least homogeneous of the four. It can thus be considered as an extension of the other sub-networks. 
facturer of Viagra $^{\mathcal{O}}$ launched the greatest hostile operation in the history of the pharmaceutical industry ${ }^{40}$.

The power of attraction-confinement thus constitutes a powerful lever for the consolidation and reinforcement of coalitions and networks. But, at the same time, it demonstrates a sort of mobility barrier ${ }^{41}$ for the one that has it. The latter could indeed find it difficult to move away from its partner, either because the contract does not provide for any real exits or because its reputation may risk being affected by it (see below).

\subsection{Intra-reticular competition}

While strategic interactions between pharmaceutical companies come into play upstream in a dynamics of network pre-emption-attraction-consolidation-stabilization, they also come into play within each network. Indeed, consolidation-stabilization strategies are only possible through the existence of relations of authority and confidence. A fight for the leadership and for sharing gains from the coalitions then come into play within each network.

The ability for a member of a network to enter into the reticular core, or even impose itself as leader, will depend mainly on its size, specificity and know-how, on its reputation and cooperation experience, on the degree of maturity of the market concerned, on the nature of interdependence between those who have formed coalitions, and on the degree of specialization and autonomy of the partners. In this way, the model leader (if there is one) would be a pharmaceutical company, a member of the hard core of the oligopoly, dominating its therapeutic market, with true expertise in its field thanks to the coalitions it was able to develop and pursue with the most advanced complementary companies, and knowing how to grant wider autonomy to the most powerful and/or useful partners.

In fact, the fight for leadership and the fight for sharing gains of the coalition appear to be linked. Indeed, sharing and the control of gains of the coalition ${ }^{42}$ depend above all on

\footnotetext{
${ }^{40}$ This operation can be explained for three main reasons: (i) Pfizer and $W L$ were already in the midst of negotiations, even if the latter came up against the degree of parity of the merger; (ii) Pfizer, who had not taken part in the recent waves of capitalistic mergers - preferring to reorganize its R\&D activities "in house", to reinforce its sales teams and to develop diversified alliances and partnerships -, had the strength and ambition to take on new markets; (iii) the creation of American Warner by $A H P$ and $W L$ questioned the co-marketing agreement concerning Lipitor $^{\mathcal{O}}$ (a cholesterol drug) signed by Pfizer and WL in 1996. However, this highly profitable drug (turnover of nearly 3.7 billion dollars in 1999; see Tab. 2) was headed for a bright future, with a potential market estimated at nearly ten billion euros... The threat of seeing $W L$ leave the Pfizer network for that of AHP seemed unacceptable for Pfizer. The latter then brought its tacit preemptive right into play, despite $W L$ management's preference for a merger between equals with $A H P$.

${ }^{41}$ There are two reasons for this mobility barrier: $(i)$ the importance of the size of the bodies and the $R \& D$ costs, which often prevent two alternative programmes from being run in the same field at the same time; (ii) confidence and experience, which very frequently cause partners to renew their coalition when the objectives have been reached.

${ }^{42}$ Gains from coalition can take on three main forms: (i) a patent, a licence or a principle agent; (ii) a method or know-how; (iii) a scientific, technical, commercial, legal, financial, cultural and organizational knowledge.
} 
the negotiation power of each member of the network and on the evolution of the power struggles between coalitions. More precisely, the ability for a leader to really affect the allocation of gains of the coalition between members of the network will depend on many factors, particularly, the functionality of the network ${ }^{43}$, the nature and degree of industrial or scientific application of the results, its own ability to absorb results, the dynamic convergence of objectives, the legal (i.e. contractual), competitive and organizational environment, the nature of decisions taken and the methods for settling conflicts and, above all the climate of confidence existing within the network (see Sako, 1991; Koenig and Van Wijk, 1992; Mothe, 1996).

\subsection{Inter-reticular competition}

Finally, the fourth level of game represents the competition between coalitions or between networks in different markets (geographical and/or therapeutic). Thus, two rival pharmaceutical companies are often seen entering into coalitions, each on its own, with biotech companies, for example, to prepare for the next generation of products. At the same time, a pharmaceutical company often enters into parallel coalitions with different partners, generally biotech companies or research centres, to bring them into competition and to pre-empt them to the detriment of other pharmaceutical companies or coalitions.

Competition between networks takes on a more complex form. To illustrate this competition, it is important to observe, for an instant, the race for decoding the human genome which opposes all the players in the sector ${ }^{44}$. The stake in this race is indeed significant when one knows that, from the identification of new targets for future drugs to understanding the mechanism of action, including the diagnosis of genetic predisposition to certain pathologies, all require gene identification (Depret and Hamdouch, $2000 \mathrm{~b}$ ). In the hope of winning (or not being outdistanced in) this race, pharmaceutical companies have two possible strategies. The first one consists in forming a coalition with one or several genomic companies (to form a coordinated network), but the extent of the task and the need to move quickly in decoding, make this strategy unsuitable. By contrast, the second strategy seems to be more suitable: generally, pharmaceutical companies prefer belonging to consortia, and thus by moving competition to the interreticular level.

Finally, it is necessary to stress that the existence and nature of inter-reticular competition, the degree of market maturity and the degree of network complexity are connected. Thus, the more mature the market concerned with the reticular rationale (traditional market), the less the firms form coalitions together, and the more the competition tends

\footnotetext{
43 It is said that a network is "monofunctional" when its activities have been clearly determined a priori, "multifunctional" when it integrates the entire innovative process (Planque, 1991), or "hybrid", when its final and intermediary functionalities cannot be defined a priori (Depret, 1999).

${ }^{44}$ In this area, three major international consortia are being considered: (i) Human Gene Consortium (private consortium with Human Genome Sciences, Smithkline Beecham, Schering Plough, Takeda, Merck KGaA, Synthélabo); (ii) SNP (see Fig. 2); (iii) Human Genome Sequencing Consortium (public consortium). It is to be noted that these three consortia are involved in a fight that has opposed them to (structural) genomic companies such as Celera (run by Craig Venter, a renegade of the public sector) or Incyte.
} 
to be at between firms. On the contrary, the less the market is mature (emerging or potential market), the more coalitions are natural and networks complex, and the more competition moves towards the coalition and reticular level.

\section{Conclusion}

Under the conjugated impact of radical and rapid technological, institutional and economic changes, the industrial and competitive organization of the pharmaceutical industry is being reconfigured deeply and durably. While the innovation processes are being structured more and more round the new biotechnological paradigm and the markets are becoming globalized and fragmented, pharmaceutical companies tend to adapt at the strategic and organizational levels, above all by refocusing their activity and by redefining all the links of their value chain. But pharmaceutical companies' strategies are undergoing the most significant changes with respect to the conception of their horizontal and vertical relations. As we have attempted to demonstrate, the innovation process and competitive dynamics are structured increasingly around firm coalitions and networks (complementary and/or rival) and around the varied institutional players, for which formation and consolidation according to a pre-emptive approach come into play upstream the markets.

We are thus witnessing the emergence of new shapes of work division in this industry in terms of R\&D and of the coordination of activities between players, of course, actually or potentially rivals, but obliged to cooperate in order to innovate, survive and possibly dominate in markets that are forever more globalized and fragmented, which are promising but also highly uncertain. In fact, while cooperation now involves strategic necessity and no longer tactical choice, this is because it constitutes the central direction for competition between the different types of firms and organizations. The drug industry indeed seems to prefigure a new type of competitive principle in the sectors subjected to radical and quick changes, according to which "innovating to compete" is no longer what counts, but "competing to cooperate and innovate together... to stay in the innovation race and the struggle for market shares" that constitutes the key to market competition and domination.

Based on this hypothetical but probable foundation of the emergence of a new technological and competitive dynamics, relatively robust and stable, it is possible to attempt to outline the changes to come about in the pharmaceutical industry:

- Re-focussing strategies are expected, both at the business and therapeutic levels, to continue. Within this scope, it is not at all certain that the combination of a commitment in the "Life Sciences" and a broader specialization strategy (the case of Aventis) will be a fruitful one, as demonstrated by the many recent examples of disinvestments (particularly that of Novartis and AHP in the agrochemical industry);

- Globalization is expected to pick up speed. Then, the penetration of large pharmaceutical groups in new markets can only come about by forming collaborations with all the local partners (institutions, firms, etc.);

- The increasingly sophisticated technology, requiring ever more mastery of different disciplines and sectors, will make it definitively utopian for a pharmaceutical company 
to alone mobilize all the competences, know-how and resources necessary to implement the innovation process. Thus, even leaders with solid commercial ground will not only have to systemize "cooperative deals", but also accentuate the formation of capitalistic coalitions to strengthen and reinforce technological and industrial networks, which explains the probable continuation of M\&A operations between large pharmaceutical companies;

- But the pharmaceutical company that is integrated vertically, seeking, developing, producing and selling its own drugs is destined to disappear. The pharmaceutical company of tomorrow will most likely be a firm whose final aim will be above all to sell, under its own brands, drug solutions (developed in house, through collaborations, subcontracted, or purchased on the market) so as to respond to a great number of new or insufficiently treated pathologies;

- The pace of innovation, the progress in knowledge of living organisms and the purely "immaterial" nature of the assets of biotechnology make a wave or acquisitions or absorptions of biotech firms by pharmaceutical companies quite unlikely (see Depret and Hamdouch, 2000a). We will therefore be witnessing more and more a confirmation of "free form of association" that will be "passionate", reasoned and well-balanced, between pharmacy and biotechnology, in what may tomorrow become more of a "healthcare industry" than a drug industry, particularly with the possibilities of cloning and cell, genetic or proteomic manipulation, as it already seems to be coming about;

- Within this framework, the exploration and exploitation of this "new biotechnology economy" will only be optimal under three conditions (Depret and Hamdouch, 2000b). Firstly, the different parties concerned must urgently rehabilitate the time factor of R\&D and remove it from a nearsighted view of the market. Secondly, the institutional framework must be consistent, harmonized and revisable, but predictable. Finally, the pharmaceutical industry must become more involved in biotech research through tighter, more lasting and more balanced collaboration, with biotech companies and university laboratories, above all by multiplying and consolidating the dense scientific and industrial networks.

Acknowledgments. The authors would like to thank Bernard Paulré and two anonymous referees for their pertinent remarks and suggestions as well as Eurasanté, the non-profit agency dedicated to economic development for biotechnology \& healthcare related activities in the Nord-Pas-de-Calais region, for its financial support in this research. Of course, we are solely responsible for any possible error or omission that may remain in the text.

\section{References}

Alvarez F. (1994) Le marché mondial des médicaments génériques. Eurostaf, Paris. Andersen Consulting (1997) Alliances: the velvet invasion \& the dual challenge, Mimeo, 23 p. Aoki M. (1991) Economie japonaise : information, motivations et marchandages. Economica, Paris.

Arthur W.B. (1988) Competing Technologies: an overview. In: Dosi G. et al. (Eds.), Technical change and economic theory. Pinter Publishers, London and New York. 
Axelsson B., Easton G. (1992) Industrial networks: a new view of reality. Routledge, London.

Béjean S., Gadreau M. (1997) Concept de réseau et analyse des mutations récentes du système de santé, Revue d'Économie Industrielle 81, pp. 77-97.

Beynon K. (2000) Feeling confident in the countdown to patent expiry, Scrip Magazine 86, pp. 31-33.

Bidault F. (1993) Apprentissage et réseaux, Économies et Sociétés W-1, pp. 79-101.

Boston Consulting Group (1999) The pharmaceutical industry into its second century from serendipity to strategy, Mimeo.

Bouabdallah K., Dufourt D. (1994) Le problème de l'évaluation de la performance des arrangements institutionnels : l'exemple des réseaux. XLIII ème Congrès annuel de l'Association Française de Science Économique, Paris.

Buisson J.P., Giorgi D. (1997) La politique du médicament. Montchrestien, Paris.

Callon M. (1991) Réseaux technico-économiques et irréversibilités. In: Boyer R. et al. (Eds.), Les figures de l'irréversibilité en économie. Presses de l'E.H.E.S.S., Paris.

Callon M. (1994) L'innovation technologique et ses mythes, Gérer et Comprendre, March, pp. $5-17$.

Callon M. (1999) Le réseau comme forme émergente et comme modalité de coordination : le cas des interactions stratégiques entre firmes industrielles et laboratoires académiques. In: Callon M. et al. (Eds.), Réseau et coordination. Economica, Paris, pp. 13-64.

Cantner U., Pyka A. (1998) Performance économique et technologique comparée des stratégies d'innovation: un modèle de simulation dynamique de concurrence monopolistique. In: Bernard J., Catin M. (Eds.), Les conditions économiques du changement technologique. L'Harmattan, Paris, pp. 63-94.

Cassier M. (1995) Les contrats de recherche entre l'université et l'industrie : l'émergence d'une nouvelle forme d'organisation industrielle, Socio-economics Thesis, École des Mines, Paris, $605 \mathrm{p}$.

Cassier M. (1998) Le partage des connaissances dans les réseaux scientifiques : l'invention de règles de « bonne conduite » par les chercheurs, Revue Française de Sociologie XXXIX, pp. 701-720.

Cassier M., Foray D. (1999) La régulation de la propriété intellectuelle dans les consortiums de recherche : les types de solutions élaborées par les chercheurs, Économie Appliquée LII, pp. 155-182.

Chesnais F. (1981) Biotechnologie et modification des structures de l'industrie chimique : quelques points de repère, Revue d'Économie Industrielle 18, pp. 218-230.

Cockburn I., Henderson R. (1998) Absorptive capacity, coauthoring behavior and the organization of research in drug discovery, Journal of Industrial Economics XVLI, pp. 157-182.

Cohen W.M., Levinthal D.A. (1989) Innovation and learning: the two faces of R\&D, Economics and Statistics 47, pp. 182-190.

Cohen W.M., Levinthal D.A. (1990) Absorptive capacity: a new perspective on learning and innovation, Administrative Science Quarterly 35, pp. 128-152.

Cohendet P., Llerena P. (1993) Apprentissage organisationnel et cohérence : l'importance économique du réseau. Colloque : Limitation de la rationalité et constitution du collectif, Cerisy, June.

Colcombet E., Aflalo C. (Mercer Management Consulting) (1995) Industrie pharmaceutique : enjeux stratégiques et perspectives 1995-1998. Les Echos Editions, Paris.

Cook K.S (1977) Exchange and Power in Networks of Interorganizational Relations, Sociological Quarterly 18, pp. 62-82. 
Dasgupta P., Stiglitz J.E. (1980) Uncertainty, industry structure and the speed of R\&D, Bell Journal of Economics 3, pp. 1-28.

De Bresson C., Amesse F. (1991) Networks of innovators: a review and introduction of the issue, Research Policy 20, pp. 363-379.

De Wolf P. (1993) L'industrie pharmaceutique. In: Sachwald F. (Ed.), L'Europe et la globalisation : acquisitions et accords dans l'industrie. Masson/IFRI, Paris, pp. 305-352.

Delapierre M. et al. (1998) Régimes de concurrence, stratégies de coopération et dynamique des structures industrielles. In : Vinokur A. (Ed.), Décisions Économiques. Economica, Paris, pp. 55-80.

Depret M.H. (1999) Nature des relations interfirmes, processus d'innovation et évolution des structures industrielles : le cas de l'industrie pharmaceutique, Mémoire de D.E.A, Faculté des Sciences Économiques et Sociales, Université de Lille I, 226 p.

Depret M.H., Hamdouch A. (2000a), F\&A dans la pharmacie : les sociétés de biotechnologies sont-elles menacées?, Biotechnologies \& Finances 12, March, pp. 6-7.

Depret M.H., Hamdouch A. (2000b), L'économie des nouvelles biotechnologies, Biofutur 200, May, pp 32-40.

Depret M.H., Hamdouch A. (2000c), Pharmacie et Biotech : l'ère des réseaux, Biofutur 203, pp. 44-48.

Dosi G. (1982) Technological paradigms and technological trajectory: a suggested interpretation of the determinants and directions of technological change, Research Policy 11, 3, pp. 147-62.

Dosi G., Teece D.J., Winter S. (1990) Les frontières des entreprises : vers une théorie de la cohérence de la grande entreprise, Revue d'Économie Industrielle 51, pp. 27-51.

Dufourt D. (1995) Introduction, Économies et Sociétés W-2, pp. 5-15.

Dumoulin J. (1994)) Innovations pharmaceutiques et réglementation : le paradigme de l'explication, Économie Appliquée XLVII, pp. 101-126.

Durand T., Gonard T. (1986) Stratégies et ruptures technologiques : le cas de l'industrie de l'insuline, Revue Française de Gestion, November-December, pp. 89-99.

Eurasanté (1999a) Biotechnologie et santé : enjeux stratégiques et perspectives dans le NordPas-de-Calais. Loos, 93 p.

Eurasanté (1999b) Les nouveaux partenariats de l'industrie pharmaceutique : l'état de l'industrie pharmaceutique dans le monde et l'externalisation croissante de ses métiers. Loos, $88 \mathrm{p}$.

Filippi M. et al. (1996) Quelles approches économiques pour la notion de réseau, Revue d'Économie Industrielle 77, pp. 87-98.

Fisher R.M., Termin P. (1973) Returns to Scale in Research and Development: What Does the Schumpeterian Hypothesis Imply?, Journal of Political Economy 81, pp. 56-70.

Foray D. (1995) Coalitions and Committees: how users get involved in information technology (IT) standardization. In: Hawkins et al. (Eds.), Standards, Innovation and Competitiveness. Edward Elgar, Aldershot, pp. 192-212.

Foray D., Le Bas C. (1991) Economie de la recherche industrielle. In: Arena R. et al., Traité d'Économie Industrielle, Economica, Paris, pp. 626-645.

Freeman C. (1995) Networks of innovations: a synthesis of research issues, Research Policy 25, pp. 499-514.

Froelicher T. (1996) L'émergence des réseaux d'entreprises : du réseau de dirigeants à la coopération interentreprises. In: Noel A., Koenig C., Koenig G. (Eds.), Perspectives en management stratégique, Tome 4, Economica, Paris, pp. 309-336. 
Fudenberg D. et al. (1983) Pre-emption, leapfrogging and competition in patent races, European Economic Review 1, pp. 3-31.

Garrette B., Dussauge P. (1991) Alliances stratégiques, mode d'emploi, Revue Française de Gestion 85, pp. 4-18.

Genet C. (1997) Quelles conditions pour la formation des biotechnopoles : une analyse dynamique, Revue d'Économie Régionale et Urbaine 3, pp. 405-424.

Gilbert R. (1989) Mobility barriers and the value of incumbency. In: Schmalensee R., Willig R.D. (Eds.), Handbook of Industrial Organization. North-Holland, Amsterdam, Vol. 1, pp. 476-535.

Grabowski H.G., Vernon J.M. (1990) A new look at the returns and risks to pharmaceutical R\&D, Management Science 36, pp. 804-821.

Grabowski H.G., Vernon J.M. (1994) Returns to R\&D on new drug introductions in the 1980s, Journal of Health Economics 13, pp. 383-406.

Granovetter M. (1985) Economic action and social structure: the problem of emdebdedness, American Journal of Sociology 91, pp. 481-510.

Guilhon B., Gianfaldoni P. (1990) Chaînes de compétences et réseaux, Revue d'Économie Industrielle 51, pp. 104-112.

Guillot F., Simon P. (1991) Coût de recherche et développement d'une nouvelle molécule, Analyse Financière 3, pp. 30-35.

Hagedoorn J., Schakenraad J. (1994) The effect of strategic technology alliances on company performance, Strategic Management Journal 15, pp. 291-309.

Hakanson H., Johanson J. (1988) Formal and Informal Cooperation in International Industrial Networks. In: Contractor F.J., Lorange P. (Eds.), Cooperative Strategies in International Business, Lexington Books.

Hamdouch A. (1998) Concurrence et coopération inter-firmes, Économie Appliquée LI, pp. 7-51.

Hamdouch A. (2000) Normalisation, coopération et stratégies concurrentielles. In: Lantner R., Foray D., Fauchart E., Hamdouch A. (Eds.), Normes et compétition internationale. Economica, Paris (forthcoming).

Hamdouch A., Depret M. H. (2000), Coalitions industrielles, réseaux de firmes et dynamiques de concurrence-coopération dans les secteurs en cours de globalisation : le cas de l'industrie pharmaceutique, Cahiers de la Maison des Sciences Économiques 2000-24, Université de Paris I - Panthéon-Sorbonne, $50 \mathrm{p}$.

Hamdouch A., Perrochon D. (1999a) Les dynamiques d'interaction entre firmes dans les secteurs intensifs en R\&D : un cadre d'analyse des principales configurations théoriques. Colloque de l'ADIS : Coopération industrielle : diversité et synthèse, Sceaux, May.

Hamdouch A., Perrochon D. (1999b) Processus d'innovation, nature des relations inter-firmes et dynamique sectorielle : le cas de l'industrie pharmaceutique. Working paper CRIFESMATISSE 97, Université de Paris I, February, 17 p.

Henderson R., Cockburn I. (1997) Taille des entreprises et productivité de la recherche du secteur pharmaceutique. In: Jacobzone S. (Ed.), Économie de la santé : trajectoires du futur, INSEE-METHODES 64-65, Economica, Paris, pp. 186-210.

Imai K., Baba Y. (1991) Systemic innovation and cross-border networks, transcending markets and hierarchies to create a new techno-economic system. In: Technology and productivity: the challenge for economic policy, O.E.C.D., Paris.

IMS (1999) Forecast of global pharmaceutical market growth. (www.ims/insight/global). 
Iung N., Rupprecht F. (1997) Productivité de la recherche et rendements d'échelle dans l'industrie pharmaceutique française, Document de travail Insee D3E, G97/16.

Jacquemin A. (1994) Capitalisme, compétition et coopération, Revue d'Économie Politique 104, pp. 501-515.

Joly P.B., Mangematin V. (1995) Les acteurs sont-ils solubles dans les réseaux ?, Economies et Sociétés W-2, pp. 17-50.

Katz M., Shapiro C. (1994) Systems Competition and Network Effects, Journal of Economic Perspectives 8, pp. 93-115.

Koenig G., Van Wijk G. (1992) Alliances interentreprises : le rôle de la confiance. In: Noël A. et al. (Eds.), Perspectives en Management Stratégique. Economica, Paris, Vol. 2.

Kotabe M., Swan S. (1995) The role of strategic alliances in high-technology new product development, Strategic Management Journal 16, pp. 621-636.

Langlois R. (1984) Internal organization in a dynamic context: some theoretical considerations. In: Jussawala M., Ebenfield H. (Eds.), Information and Communication Economics: New Perspectives. North-Holland, Amsterdam.

Lazega E. (1996) Arrangements contractuels et structures relationnelles, Revue Française de Sociologie XXXVII, pp. 439-456.

Lemieux V. (1998) Les coalitions : liens, transactions et contrôles. P.U.F., Paris.

Lesourne J., Orléan A. (1998) Advances in Self-Organization \& Evolutionary Economics, Economica, Paris.

Maillat D. et al. (1991) Réseaux d'innovation et dynamique territoriale : un essai de typologie, Revue d'Économie Régionale et Urbaine 3-4, pp. 407-432.

Mairesse J., Mohnen P. (1990) Recherche-Développement et productivité : un survol de la littérature économétrique, Économie et Statistique 237-238, pp. 99-108.

Martin E.; Rupprecht F. (1998) Les enjeux des médicaments génériques, Économie et Statistiques 312-313, pp. 55-66.

Massard N. (1997) Externalités, apprentissage et dynamique technologique : un retour sur la notion de réseau. In: Guilhon B. et al., Economie de la connaissance et organisations : entreprises, territoires, réseaux. L'Harmattan, Paris, pp. 336-355.

Maupertuis M.A (1997) Nature et rôle de la coopération interfirmes dans le processus de changement technologique : l'exemple de la biotechnologie. In: Froehlincher T., Vendemini S. (Eds), Connivences d'Acteurs, Contrats, Coopération inter-entreprises et métamorphoses des Organisations, Presses Universitaires de Nancy, pp. 131-149.

Mothe C. (1996) L'appropriation des résultats au sein de consortia de R\&D. In: Noël A. et al. (Eds.), Perspectives en Management Stratégique, Tome 4. Economica, Paris, pp. 381-406.

O.C.D.E. (1985) L'industrie pharmaceutique : questions liées aux échanges. OCDE Publications, Paris.

Panzar J., Willig R. (1981) Economies of Scope, American Economic Review 71, pp. 268-272.

Paulré B. (1997) Evolutionnisme contemporain et auto-organisation, Économie Appliquée L, pp. 121-150.

Perrin J.-L. (1991) Réseaux d'innovation, milieux d'innovation et développement territorial, Revue d'Économie Régionale et Urbaine 3-4, pp. 343-374.

Perrochon D. (2000) Le recentrage dans l'industrie pharmaceutique : vers une redéfinition des métiers de la santé. In: Paulré B. (Ed), Les stratégies de recentrage dans les secteurs de haute technologie. Chimie, Pharmacie, Informatique, Télécommunications, Ministère de l'Économie, des Finances et de l'Industrie, Direction Générale de l'Industrie, des Technologies, de 
l'Information et des Postes, Collection Études, February, Paris, Editions de l'Industrie, pp. 125-190.

Pfeffer J., Salancik G.R. (1978) The External Control of Organizations: A Resource Dependence Perspective. Harper and Row, New-York.

Pharmaceutical Executive (2000) Top 50 Pharmaceutical Companies of 1999, 10 p., (http:// www.pharmaportal.com/articles/top50.pdf).

Pharmaprojects (2000) What are the latest industry developments?, Figure 3: Top 25 companies based on the number of active products in their R\&D pipelines, (http://www.pjbpubs.co.uk/ pharma/index.html).

PhRMA (2000) Pharmaceutical Industry Profile 2000, (http://www.phrma.org/publications/ industry/profile00/).

Planque B. (1991) Note sur la notion de réseau d'innovation, Revue d'Économie Régionale et Urbaine 3-4, pp. 295-320.

Porter M.E. (1993) L'avantage concurrentiel des Nations. InterEditions, Paris.

Porter M.E., Fuller M.B. (1986) Coalitions and global strategy. In: Porter M.E. (Ed.), Competition in global industries. Harvard Business School Press, Cambridge (Mass.), pp. 315-343.

Powell W.W. (1990) Neither market nor hierarchy: network forms of organization, Research in Organization Behaviour 12.

PriceWaterhouseCoopers (1999) Pharmaceutical executive briefing 1998, PWC.

Quéré M., Ravix J.L. (1996) Les relations science-industrie : analyse des procédures d'accès à des activités nouvelles. In: Ravix J.L. (Ed.), Coopération entre les entreprises et organisation industrielle. Editions du CNRS, Paris, pp. 267-284.

Raugel P.J. (1993) Les sociétés spécialisées en biotechnologies : stratégies, environnement industriel et financier. In: Scriban R. (Ed.), Biotechnologie, Lavoisier, Paris, pp. 773-813.

Rhône-Poulenc-Rorer (1998) Rapport d'Activité.

Richard D., Senon J.L. (1996) Le médicament. Flammarion, Paris.

Richardson G.B. (1972) The Organization of Industry, Economic Journal 82, 327, pp. 883-896.

Rivière P. (1997) Esquisse d'une typologie des réseaux. In: INSEE, Les réseaux d'entreprises : des collectifs singuliers, Insee-Méthodes 67-68.

Rosier F. (1999), La course aux “snips” bat son plein, Biofutur 194, pp. 84-86.

S.N.I.P. (1997) L'Industrie pharmaceutique, ses réalités. SEFEFIM, Paris.

S.N.I.P. (1999) Les chiffres clés. (www.snip.fr/industrie/presentation).

Sako M. (1991) The role of "trust" in Japanese buyer-supplier relationships, Ricerche Economiche XLV, pp. 375-399.

Schumpeter J.A. (1961) The Theory of Economic Development. An Inquiry into Profit, Capital, Credit, Interest and the Business Cycle. Oxford University Press, Oxford.

Sharp M. et al. (1994) Transferts de technologie et politique de l'innovation : le cas des biotechnologies. In: Sachwald F. (Ed.), Les défis de la mondialisation innovation et concurrence. Masson/IFRI, Paris, pp. 155-212.

Spikler B. (1993) Multinational pharmaceutical companies: principles and practices. Raven Press.

Staropoli C. (1998) Cooperation in R\&D through a network, an "organizational gamble"? An empirical analysis of Rhône-Poulenc Rorer-Gencell, Technology Analysis \& Strategic Management 10, pp. 511-527.

Stengers I. (1985) Les généalogies de l'auto-organisation, Cahiers du CREA: Généalogies de l'auto-organisation $\mathbf{8}$, November. 
Tarabusi C.C. (1993) Globalisation de l'industrie pharmaceutique : évolution technologique et concurrence dans la perspective de la triade, STI 13, pp. 139-180.

Tarabusi C.C., Vickery G. (1996) La mondialisation de l'industrie pharmaceutique. In: O.C.D.E., La mondialisation de l'industrie : vue d'ensemble et rapports sectoriels, pp. 81125.

Teece D.J. (1992) Competition, cooperation, and innovation - Organizational arrangements for regimes of rapid technological progress, Journal of Economic Behavior and Organization 18, pp. 1-25.

Thorelli H.B. (1986) Networks: between markets and hierarchies, Strategic Management Journal 7, 1, pp. 37-51.

Von Neumann J., Morgenstern O. (1944) Theory of Games and Economic Behavior. Princeton University Press.

Waelbroeck-Rocha E. (1997) La cohérence des politiques de l'Union européenne en matière de commerce, de concurrence et d'industrie dans le secteur pharmaceutique. In: Jacobzone S. (Ed.), Economie de la santé : trajectoires du futur. INSEE METHODES 64-65. Economica, Paris.

Yovits M.C., Jacobi G.T., Goldstein G.D. (1962) Self-organizing systems. Spartan Books, Washington.

to access this journal online: www.edpsciences.org 